Makale Gönderim Tarihi: 18.05.2019

Makale Kabul Tarihi: 30.07.2019

\title{
ŞA'IR Û NIVÎSKAR XEMKÛRÊ XURSÎ: JÎYAN, BERHEM Û KESAYETÎYA WÎ YA EDEBî
}

\author{
M.Zahir Ertekin ${ }^{1}$ \\ Nurettin Ertekin ${ }^{2}$
}

\section{KURTE}

Edîbên nenas û berhemên wan, di edebîyata kurdî da qadeke serbixwe ye. Lewra lêgerîn û vekolîna li ser edîb û berhemên edebî ji bo kurdî û kurdan mijareke ter û teze ye. Loma roj bi roj şa'ir, nivîskar û berhemên nû yên vê biwarê derdikevin rojevê. Mijara gotara me, edîbekî sedsala me yê ku heta niha nehatîye nasîn e. Xemkûrê Xursî, yek ji şair û nivîskarê edebîyata kurdî ya klasîk e. Berhemên wî; 2 pexşan, 11 menzûm bi tevahî 13 heb in. Ji vana 8 heb dîwanên serbixwe ne. Heta niha tu berhemên wî nehatine çapkirin û heta niha li ser wî xebat jî nehatine kirin. Di vê gotarê da em ê li ser jiyana Xemkûr, berhemên wî û naveroka wan û kesayetîya wî ya edebî rawestin. Herwiha wê berhemên wî ji alîyê şêwaznasî, ziman û temayî ve jî were helsengandin. Bi vî awayî 13 berhemên nû-destxet wê li pirtûkxaneya kurdî bêne zêde kirin. Ji alîyekî din ve bi vê gotarê em ê balê bikişînin ser vî edîbî da ku peywendîdar jê hayidar bibin û derfeta xebatên mezintir derkeve holê, di dahatûyê da.

Peyvên Sereke: Xemkûrê Xursî, Dîwan, Mewlûd, Telqîna Mirîyan, Helbesta Kurmancî

\footnotetext{
${ }^{1}$ Doç.Dr., Bingöl Üniversitesi, Yaşayan Diller Enstitüsü, Kürt Dili ve Edebiyatı Anabilim Dalı, zahirertekin@hotmail.com, Orcid: 0000-0003-3519-9892

2 nurettin.ertekin@hotmail.com,
} 


\title{
Yazar ve Şair Xemkûrê Xursî: Hayatı, Eserleri ve Edebi Kișiliği
}

\begin{abstract}
ÖZET
Bugüne kadar haklarında malumat sahibi olmadığımız, gün yüzü görmemiş şair ve yazarlar, Kürt edebiyatı için başlı başına bir çalışma sahasıdır. Çünkü bu tür şahsiyetler, Kürt edebiyatı araştırmaları için bakir bir alan teşkil etmektedir. Bu tür çalışmalar sayesinden gün geçtikçe klasik Kürt edebiyatı hakkında yeni veriler ortaya çıkmaktadır. Bu makale, henüz hayatta olan ve şimdiye kadar tanınmayan bir şairin hayatı ve eserlerini konu edinmektedir. Xemkûrê Xursî klasik Kürt edebiyatı şair ve yazarlarındandır. 2 tanesi nesir 11'i nazım olmak üzere 13 eseri bulunmaktadır. Bu 11 nazım türü eserinden 8'i klasik edebiyatın önemli bir türü olan divan türü eserlerdi. Xemkûr'un eserleri hakkında bugüne kadar herhangi bir çalışma yapılmadığı gibi, herhangi bir eseri de yayınlanmamıştır. Bu çalışmada şair ve yazar Xemkûr'un hayatı, eserleri, eserlerinin içeriği ve edebi kişiliği üzerinde durulacaktır. Ayrıca eserlerinin dil ve üslup özellikleri, şiirlerinde tema da mercek altına alınacaktır. Bu çalışma ile bugüne kadar hiç bilmeyen 13 Kürtçe eserin varlığı tescillenmiş olacak ve alan araştırmaları için yeni bir inceleme konusunun kapıları aralanmış olacaktır.
\end{abstract}

Anahtar Kelimeler: Xemkûrê Xursî, Divan, Mevlid, Ölüm Telkini, Kürt Şiiri

\section{Xemkîrê Xursî, A Poet and Writer: His Life, Works and Literary Personality}

\begin{abstract}
The unkown men of letters and their works form a private and an independent domain in Kurdish literature, for surveys and studies concerning new writers and their literary works may be considered as untouched and fresh topics to be dealt with both for Kurdish and Kurds. Hardly a day passes without exploring a new poet, author and his works that are put in the agenda. The subject of our article is a contemporary man of letters who has not been recognized yet. Xemkûrê Xursî is amongst the classical poets and writers of Kurdish. He is the owner of 13 works in total, 2 of which are in prose and remaining ones in poetry. 8 of his poetical works constitute separate diwans. None of his works has been published nor has it been reviewed by anyone up to now. This article aims at dealing with Xemkûr's life, his works, their literary contents and his literary personality. Furthermore his works are examined and described through various criteria such as methodogy, style and theme. As a consequent the Kurdish library will be privileged to know 13 newhand written manuscripts. As a last point to mention, this study will potentially lead the curious reader to learn more about him and to conduct more comprehensive studies in the future.
\end{abstract}

Keywords: Xemkûrê Xursî, Dîwan, Mewlûd, Telqîna Mirîyan, Kurmancî Poems

\section{Destpêk}

Neheqîyek e ku helbestvanên li heyatê gelek cara nabin mijara vekolînan. Ango pir nakevin qada lêkolînê. Çawa ku hemû helbestvanên kevin û mirî bi hêz û şêwexurt nînîn, hemû helbestvanên nû jî xerab û bêuslûb û nejêhatî nînin. Berovajî vê, eger nivîskarek an helbestvanekî milletekî, li jîyanê be, bi çavên serê xwe çapa berhemên xwe bibîne, bibîne di semînerekê, sempozyomekê yan di panelekê de mijarek li ser wî hatîye amadekirin, an tezek, berhemek, lêkolînek li ser berhemên wî bête kirin, şanazîyek e, xêrxwazîyek e ji bo wî. Herwiha taltîfkirina wî ye ev, û hêz û quweta qelema wî jî bi vê enerjîyê zêdetir dibe. Nexwe divê felsefeya "hêj li heyatê ye, hewceyê xebatê nîne" were red û 
tard kirin. Ma rewa ye meriv li bendî mirina kesên wisa; edîb û helbestvanên xwe, dengbêj û qesîdevanên xwe bisekine. Vêja helbestvanê ku bûye mijara vê gotarê li heyatê ye û xebatên wî hêjayî lêkolînên akademîk in.

Armanca vê nivîsarê danasîna Xemkûrê Xursî ye ku heta niha tu berhemên wî çap nebûne. Lewra tibabek berhem nivîsandine û hemû jî tenê li ber destê wî ne. Bi vê gotarê em dixwazin wî vekolînin û derxînin ser qada lêkolînerîyê. Piştre vekolîner dikarin yek bi yek an cure bi cure li ser helbestên wî, şêwaza wî, zimanê wî û hwd. lêbikolin. Me tenê nîyet ev e; derîyekî din li pirtûkxaneya kurdî vekin, vî nenasî bidin nasîn û bala raya peywendîdaran bikêşin ser wî. Lewra heta niha tu xebat li ser wî û berhemên wî nehatine kirin. Me jî bi vê berpirsiyarîyê bala xwe da ser vî helbestvanî.

Di nivîsê da du cureyên vegotinê hene. Yek jê nezm e ango şi'r e. Yek jî nesr e ango pexşan e. Eger hest, raman, daxwaz an xeyalek, bi awayekî pîvanî û bi kafîye hatibe ristin, ji van risteyan re nezm/şi’r tê gotin. Di nezmê da tişta herî girîng unsûrên ahengê ne. Di şi'rê de xeyal, nepixandin, îstî̀'are, mecaz û şibandin... zêde bi bandor in. Eger ev tişt nebin, ew risteyên dirêj nabin helbest. Yanî ji bo nezmek wek şi'r bête pejirandin divê alîyê wê yê hunerwarî hebe. Vêca hin menzûme jî hen in ku di teşeya nezmê da têne nivîsandin; lê bele şi'r nînin. Tenê, berhem di forma şi'ran de tên nivîsandin. Mebesta wê cuda ye û taybetîyên şi'rê di wan da tune. Xemkûr bi hersê cureyan jî berhem nivîsandine. Şi'rên wî henin, menzûmeyên wî henin û berhemên wî yên pexşanî jî henin. Xemkûr 8 dîwanên şi'ran, 3 menzûmeyên dîdaktîkî û 2 berhemên pexşan nivîsandine. Di çarçoveya 3 kategorîyan de em ê li ser van berhemên wî rawestin.

Di vê gotarê de sê beş hene. Beşa yekem kurtejîyana şai'rî ye. Ya duyem senifandin û danasîna şiklî û naverokî ya berhemên wî ne. Di beşa sêyem de jî kesayetîya wî ya edebî hatîye vekolîn.

\section{A. KURTEJÎYANA XEMKÛR}

Navê wî, Mihemed Helîm e. ${ }^{3}$ Lawê Ehmed ê Se'dûn e, Se'dûn lawê Mihemed e, Mihemed lawê 'Emo ye, 'Emo lawê 'Elî ye, 'Elî lawê 'Emo ye, 'Emo ji Bişêrîyê ji ber dujminantîyê mala xwe bar dike, direve tê Aqresa Mêrdînê. Li Aqresê gelek salan dimînin. Li vir debara xwe bi danîn û rakirina rezan dikin.

Şevekê di nava rez da li ser nimêja 'eşayê 'Emo ji teref dujminên xwe ve tê kuştin. Malbata 'Emo bi hizra Aqresîyan alikarîya dujminên wan kirine, cenazeyê 'Emo yekser tînîn li Xursê vedişêrin. Malbat venagere Aqresê. Xursî diçin mal û tiştên wan bar dikin tînin gundê xwe û wan li wir bicih dikin.

\footnotetext{
${ }^{3}$ Hemû agahîyên derbarê Jîyan, xwendin û helbestvanîya Xemkûrî Xursî (Mela Mehemed Helîm) k udi vê gotarê da hatîye nivîsandin, di dîroka 23/11/2018da li Amedê li mala Seyda ji devê Seyda hatîye wertgirtin. Piştî gotar hate nivîsandin, di dîroka 24/02/2019da gotar bi giştî ji Seyda ra hate xwendîn û destûra weşandinê jê hate wergirtin.
} 
Xurs, herêmeke di navbera Qoser û Şemrexê de dimîne. Ji 12 gundan pêk tê. Malbata 'Emo, ji gundê Xursê yê ku bi navê Xursa Jorîn (Heftêxwehan) da warnişîn dibin. Mela Mihemed Helîm di 25/12/1945an da li Xursa Jorîn tê dinyayê.

\section{Xwendina Wî}

Xemkûr, berîya ku dest bi xwendina medreseyê bike bapîra wî, wî fêrî nimêjê dike. Xuyaye di maleke dîndar da perwerde bûye. Di destpêkê da li gundê 'Izêr (girêdayî Qoserê) li ber destê Sofî 'Elî dest bi xwendina Quranê dike.

Mihemed, di xwendinê da gelek zîrek e. Di du mehan da cizûya 'emayê diqedîne. Piştre rojê cizûkê diqedîne. Mihemed, di du meh û bîst û neh rojan da Quranê xitim dike. Piştre li Qoserê li cem xalê xwe Kazim Quranê carî dike.

Li gundê Girbellê li cem Mela Ehmedê Şêx Remo dest bi xwendina Xayetê $\hat{e}^{4}$ dike. Mihemed Helîm wê demê neh salî ye. Mihemed Helîm û Mela 'Ebdurrehman ji Şemamîyê diçin Qurtelanê, li gundê Têlanê li cem Şêx Mihemmed Siddîq dest bi xwendina medreseyê dike. Li vir 'Izzîy $\hat{e}^{5}$ dixwîne. Emsîle û Binayê $\hat{e}^{6}$ xwe bi xwe dixwîne, van berhema bi derskî nastîne.

Ji Têlanê tê gundê Hesena ku gundeki Şemrexê ye, li cem Seydayê Melle 'Elî 'Ewamilể dixwîne. Ji vir diçe Hêşerîya Qoserê li cem Seydayê Melle Xidirê Hêş̧erî xwendina xwe didomîne. Ji Hêşerîyê diçe Qesrîk li ba Seydayê Melle Hadîyê Xerabazinî Hel û Netayicê ${ }^{8}$ dixwîne. Ji Qesrîkê dîsa vedigere Hesena li ba Seydayê Melle 'Elî Se'dulla Gewra ${ }^{9}$ û Sîyûtî ${ }^{10}$ dixwîne.

Ji Hesena tê gundê 'Izêr, li cem Seydayê Melle 'Ebdulhemîdê Helêla Camîyê ${ }^{11}$ dixwîne. Ji vir berê xwe dide Êlihê li cem Şêx Fexreddîn; Camî, $\hat{I}_{\text {saxoc }}{ }^{12}$ û berhemên din dixwîne. Dema Cemu'l-Cewami 'ế ${ }^{13}$ dixwîne bavê wî rehmet dike. Bi sedema wefata bavê wî kar û barên malê dikeve situyê wî, ji ber hindê di sala 1965an da dev ji xwendina xwe berdide.

\footnotetext{
${ }^{4}$ Xayet'ul-Îxtîsar. Ebû Şuca' el-Îsfehanî (m 1106 m.) nivîsandiye. Derbarê Fiqha Şafi'î da ye (Newayî, 2018, r. 43).

5 El-'Izzî. Ji teref Izzuddîn ez-Zencanî (m 655-1256) hatiye nûsîn. Berhemek li ser serfa Erebî ye (Newayî, 2018, r. 43).

${ }^{6}$ Navên du berhemên serfa Erebî ne. Nivîskarên wan nayên zanîn (Newayî, 2018, r. 43).

${ }^{7}$ Navê berhemê El-'Ewamil e. Abdulqahir bin Ebdurrehman el-Curcanî (m. 474/1080) nivîsîye. Mijar nehwa Erebî ye (Newayî, 2018, r. 43).

${ }^{8}$ Kitêba nehwê ye. ji teref Ehmed bin Mûhemmed el Henefî (m 1597) hatîye nivîsandin. Navê berhemê: Hellu'l-Me'aqid Şerhu'l-Qewa'id e (Newayî, 2018, r. 44).

9 Heda'îqu'd-Deqaîq. Se'deddîn Se'dullah nivîsîye. Di derbarê nehwa Erebî da ye (Newayî, 2018, r. 44).

${ }^{10}$ Celaleddîn es-Suyûtî (1455-1505) nivîsandiye. Li ser nehwa Erebî ye (Newayî, 2018, r. 44).

${ }^{11}$ Fewa'idu'd-Diya'iyye ye. Di nava feqiyan da binavê Mela Camî tê nasîn. Ji teref Mewlana Camî (Nûreddîn el-Camî ( m.1490 M)) hatîye nivîsandin. Berhemek li ser nehwa Erebî ye (Newayî, 2018, r. 45).

${ }^{12}$ Îsaxocî/ er-Rîsaletu'l-Esîriyye. Derbarê zanista mentiqê da ye. Mufeddel bin Umer Ebherî (m 1264 M) nivîsîye (Newayî, 2018, r. 45).

${ }^{13}$ Ebdulwehab bin Elî es-Subkî (1327-1370 M) nivîsîye. Di derbarê usûla tefsir, hedîs, fikih û kelamê da ye (Newayî, 2018, r. 45-46).
} 
Di sala 1968an da dizewice. Ji vê zewacê 8 zarok çêdibin. Zarokê yekem (lawik) û zaroka dawî (keçik) hîn bi biçûkayî wefat dikin. 5 kur û keçeke seyda li jîyanê ne û zewîcîne û bûne xwedî mal.

Di sala 1972an da Xemkûr mala xwe tîne Amedê. Piştî hin karên cuda di sala 1973yan da, di sazîyeke fermî da, dest bi kar dike û di sala 1996an da ji heman sazîyê malnişîn dibe. Piştî teqawitê hinek karê bazirganîyê dike û di sala 2009an da dev ji bazirganîyê berdide. Niha li navenda Amedê niştecih e.

\section{Helbestvanîya Wî}

Di dema feqîtîya wî da hewesa helbestvanîyê pê re çêdibe. Di nav feqîyan da helbestên helbestvanan dixwîne. Li gorî wî dengê wî xweş e û heval dixwazin ku ew bi deng ji wan ra helbestan bixwîne. Di feqîtîyê da yekem helbesta xwe dihone. Ev helbest mulemma'ek e du zimanî; kurdî û erebî ye. Helbest bi van beytan dest pê dike;

"Leha lewn'u-l munewwer sore wek gul

We înnî 'aşîqun ke mislî bulbul

\section{Ewî wechê mûdewwer çavê ebleq}

Helandin wan li min can $\hat{u}$ cîger, dil" ${ }^{14}$

Di wê demê da li nav feqîyan helbestên Cegerxwînî di rewacê da ne. Seyda helbestên Cegerxwîn (1903-1984) jî dixwîne. Herwiha helbestên seyda ji xwe re bijartine di defterekê da dinivîse. Lê leşkerêkî kurd ê Erziromê deftera seyda bi tehdît jê distîne. Seyda dibêje di wê defterê da hin helbestên Cegerxwîn hebûn ku me ji xwe re tomar kiribûn îro em di dîwanên wî yên çapbûyî da nabînin. Bivê nevê Cegerxwîn bi helbestên xwe bandorek li seyda kirîye.

Sedema helbestvanîya Xemkûr 'işqa Resûlê Xweda ye. Dilê wî ji mêj ve bi 'işqa Resûlê Xweda diqilqil e. Seyda çi dema rastî Rewdu'n-Ne'îma Şêx Ebdurrehmanê Aqtepî (1854-1910) tê û dixwîne 'işqa Resûlê Xweda di dilê wî de hîn bêtir geş dibe. Hem di 'işqa Resûlê Xweda da û hem di nivîsandina helbestan de Rewdu'n-Ne'îm bandoreke girîng li seyda dike. Seyda dibêje Rewdu'n-Ne'îmê zêde zêde ez teşwîq kirim li ser nivîsandin û honandina helbestan. Xemkûr vê bandorê di helbestên xwe da eşkere dike.

\section{B. BERHEMÊN Wî}

\section{a. Berhemên Pexşan}

Weke li jor jî hate gotin tu berhemên Xemkûr nehatine çapkirin. Hemû li ber destê wî; yan bi destxeta erebî yan li nav kompîturê bi tîpên latînî hatine parastin. Berhemên pexşan ên Xemkûr hemû dînî û didaktik in. Dema meriv li

${ }^{14}$ Ev helbest di dîwanên Xemkûr da bi cih nebûye. Lewra hemû helbest nayê hişê wî. Tenê çar çarîn tê bîra wî. Me ev helbest û berdewama wî bi dengê Xemkûr qeyd û tomar kir. 
naveroka wan dinihêre, tê dîtin nivîskar xwestîye rê li ber însanan bixe û tiştinan hînî wan bike. Ev berhem, wekî rênişanderan jî dikare bên hesibandin. Bi taybet di mijarên dînî da bikaranîna zimanê zikmakî jî yek jî sedemên nivîsandina van berheman e. Bo nimûne telqîna mirîyan, heta îro jî li nav kurdan bi 'erebî tête xwendin. Xemkûr belkî pêngava yekem avêtîye û ev telqîn bi kurdî nivîsîye. Armanc ji nivîsandina bi kurdî, hêsankirina têgihiştina gel û aktîfkirina zimanê dayikê di qadên jîyana rojane û dînî da ye.

\section{Telqîna Mirîyan}

Berhem ji 4 rûpelan pêk tê. Bi besmeleyê dest pê dike. Nivîskar di dawîya berhemê da dîyar dike ku ev berhem di meha remezana 2005an da hatîye nivîsîn û cîyê nivîsîna wê Amed/Dîyarbekir e. Xusûsîyeta vê berhemê ya berbiçav ev e; berhem xwerû kurdî/kurmancî ye û heta ji destê nivîskar hatîye kurdîya xwe ji peyvên 'erebî vala kirîye û kurmancîya di nav gel bi kar anîye. (Xursî, Telqîna Mirîya)

\section{Pirs û Bersivên Ol û Dînê Îslamê}

Berhem ji 79 rûpelên A4 pêk hatîye. Tarîxa nivîsandina berhemê dîyar nîne. Li binê rûpelê dawî cîyê nivîsînê û navê nîvîskar wiha hatîye nivîsandin: Mehemmed Helîm ê Xursa Heftêxwehan, Qoser / Mêrdîn. Bi vê dîyar e nivîskar berhema xwe li gundê Qoserê/Qiziltepe Xursê nivîsîye. Di destpêkê da nivîskar wiha eşkere dike ku çima ev pirtûk nivîsîye û ji nivîsandina vê berhemê hedefa wî çi ye:

"Me hewl da ku di warê ol $\hat{u}$ dînê Îslamê de; alikarîyek zanistî bi biçûkên xwe yên kurdan ra bikim. Piştî xebat $\hat{u}$ lêkolînek dirêj me pirtûkek biçuçik bi navê pirs $\hat{u}$ bersivên olî ji biçûkên xwe kurdan ra amade kir û pêş̧êş̧î wan kirin. Em hêvî dikin ku hinek ji biçûkên me kurdan jî̀; ji van pirs $\hat{u}$ bersivên kurt sûd wergirin $\hat{u}$ nezan nemînin. Ked $\hat{u}$ xebat ji me û alikarî jî ji Xwedayê dilovîn û dilovan".

Ji vegotina nivîskar jî dîyar dibe, wî xwestîye zarokên kurdan ji layê dînî ve perwerde bike. Herwiha bi awayekî sivik û balkêşane, bi pirs û bersivan giranîya xwendina pirtûkê ji holê rakirîye. Di hin bersivên pirsan da nivîskar çavkanîyên ku ji wan sûd wergirtine destnîşan kirîye (Xursî, Pirs $\hat{u}$ Bersivên Ol $\hat{u}$ Dînê Îslamê, r. 20). Berhem ji 5 beşan pêk hatîye.

Beşa yekem Binghên Olî yên Sereke ye. Di vê beşê da pirsên wek çend cûre ol hene? Taybetîyên ola îslamê çi ne? Îman çi ye? Navê pirtûka pîroz a îslamê çi ye? Em ê çawa Xweda nas bikin û wd. cih digirin. Bi vî rengî 55 pirs hatine pirsîn û bersivên wan hatine dayîn.

Beşa duyem perestîş ango îbadet e. Ev beş bi pirsa armanca afirandina însan dest pê dike û bi pirs û bersivên derbarê 'ibadetê da didome. Ev beş zêdetir li ser 
helal û heraman, şêweya pêkanîna 'ibadetan, cureyên wan û hukmê wan radiweste. Di vê beşê da bi tevahî 72 pirs hatine bersivandin.

Beşa sêyem Sîyer e. Ev beş pirsên derbarê jîyana hz. Pêxember (s.x.l.) di hundirê xwe da dicivîne. Ji 21 pirs û bersivan pêk hatîye.

Beşa çarem Sinc û Exlaqê Olî ye. Bi ayet û hedîsan pirsên vê beşê hatine rave kirin. Bêtir li ser pirsên wek misilman divê çawa tevbigerin? Li gorî hedîs û Quranê divê sinca misilmanan çawa be hatîye rawestandin. Nivîskar di bersiva pirsa sinc û exlaqê hz. Pêxember çawa bû? da gelek çavkanîyan dide ${ }^{15}$. Ev beş bi tavahî 20 pirs û bersiv in.

Di beşa pêncem da mijar Çanda Giştî ye. Pirsên derbarê al, niştiman, welat, dewlet, mewlûd, rojên pîroz, kar û barên dînî yên fermî û h.w.d. hatine bersivandin. Bi tevahî 13 pirs û bersiv di vê beşê da hatine bi cih kirin. Di dawîya vê beşê da binbeşeke bi serê xwe jî heye ku weke pirs hatîye nivîsîn, navê wê; Tevgerên di Ol û Dînê Îslamê da Qedexe (Heram) Çi ne? Li binê vê pirsa taybet 207 heram ango qedexe hatîye nivîsîn.

Zimanê berhemê rewan û rojane ye. Xuyaye nivîskar bi taybet xwestîye ziman sivik be. Lewra bêtir ji bo zarokan nivîsîye. Ji ber ku mijar dînî ye, nivîskar ji bo termînolojîya dînê îslamê têgehên nû yên kurmancî çênekirîye. Termînolojîya dînê îslamê her wekî resenîya wê pejirandîye û bi kar anîye. Lê çend têgehên ku wî bi xwe çêkirine jî hene. Bo nimûne ji bo wehyê, peyxam bi kar anîye (Xursî, Pirs $\hat{u}$ Bersivên Ol û Dînê Îslamê, r. 12). Ji bo meala tirkî kurtewate bi kar anîye

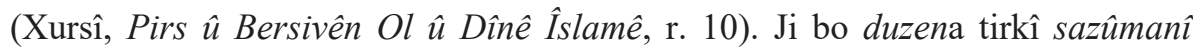
(Xursî, Pirs î Bersivên Ol û Dînê Islamê, r. 10), ji bo tewekkulê spartin (Xursî,

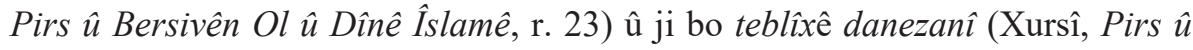
Bersivên Ol û Dînê Îslamê, r. 21) bi kar anîye.

\section{b. Berhemên Menzûm}

\section{Mewlûd}

Mewlûda Seyda ji 69 rûpelan pêk tê. Ji destpêkekê, (destpêk ji 31 malikan pêk tê) û 18 beşan pêk tê. Piştî beşa dawî bi awayê pexşan beşa duayê cih digire. Piştî duayê ferhengoka mewlûdê ango ferhengoka kurdî-tirkî cih girtîye. Piştî ferhengokê çavkanîyên mewlûdê hatîye nivîsîn. Xemkûr berhema xwe li Amedê di meha Remezanê da, di sala 2005an da temam dike (Xursî, Mewlûda Kurdî, r. 69). Mewlûd di qafîyeya mesnewîyê da (aa, bb. cc. dd...) hatîye nivîsandin. Wezna wê ya erûzê Fa'îlatûn / fa'îlatûn/ fa'îlûn û Remelê 6 pêngavîyê mehzûf e. Di hin malikan de wezin vediguhere ser Remelê 6 pêngaviya meqsûr;

\footnotetext{
${ }^{15}$ Wek mînak ji bo bersiva vê pirsê ev çavkanî hatine bikaranîn. 1 Sûretê Qelem - ayet: 4. 2 Muslim, 1/514 (Nimra Hedîsê: 746; Yücel, İrfan, Jiyana Pêxember, Sh. 264, Weşana Diyanetê) 3 Sahîhî Muslim, 1/535 (Nimra Hedîsê: 771). 4 El- Buxarî, 4/166; Muslim, 4/1810 (Nimra Hedîsê No: 2321) Wergera Tecridê. 9/318 (Nimra Hedîsê: 1456)
} 
Fa'îlatûn / fa'îlatûn / fa'ilan. Naveroka berhemê ji sernavên beşan eşkere dibe. Em ê tenê navê beşan binivîsin û nekevin kûrahîya beşan. Beşên mewlûdê ev in;

1. Destpêk

2. Şopandina Kuştina 'Ebdullah

3. Zewaca 'Ebdullah û Amîneyê

4. 'Elametên ku 'Ebdullah Dîtine

5. Wefata 'Ebdullah

6. Xewnên Amîneyê

7. Jidayikbûna Mûhemmed(s.x.l)

8. Nîşanên Bi Xwedê Dayîn a Mûhemmed ra Hatine Dîtin

9. Mûcîzatên ku Helîmeyê Berî Anîna Mûhemmed Dîtine

10. Mucîzatên ku Helîmeyê û Zarokên Xwe Dîtine

11. Mucîzatên ku Helîmeyê Mûhemmed Radestî Malbata Wî Kirîye Dîtine

12. Wefata Hezretî Amîneyê

13. Mucîzatên Mûhemmed (a.s.)

14. Xêra Selewatan

15. Sekna Rêzgirtinê

16. Duâ û Hewîș

\section{Pêdivîyên Ol û Dînê Îslamî (Eqîda Îmanê)}

Berhem ji 23 beş û ferhengokeke dirêj pêk hatîye. Berhem cur bi cur mijarên 'eqîleyê dihundurîne. Li gorî dabeşkirina helbestvan beşên berhemê ev in;

1- Beşa Yekem: ferz û 'eyn

2- Beşa Duyem: şertên îmanê

3- Beşa Sêyem: ruknên îslamê

4- Beşa Çaran: rengdêrên cuda (sîfatên selbîye )

5- Beşa Pêncan: rengdêrên mayende (sîfatên qedîm)

6- Beşa Şeşan: bawerîya bi hebûna (ferîşteyên Xuda)

7- Beşa Heftan: pesnê Mûhemmed (s.a.w)

8- Beşa Heştan: behsa mîracê

9- Beşa Nehan: mirovên li cem Xwedê herî bi rûmet

10-Beşa Dehan: resûl û nebî û pirtûkên Xuda

11-Beşa Yazdehan: dia û hewîş

12-Beşa Dwazdehan: bê emirîya îmaman

13-Beşa Sêzdehan teqdîr û tevdîr

14-Beşa Çardehan: nîşanên qîyametê

15-Beşa Pazdehan: 'ezabê gorê

16-Beşa Şazdehan: heşr û hesab û mîzan

17-Beşa Hivdehan: pira selatê

18-Beşa Hijdehan: mezhebên olî

19-Beşa Nozdehan: sinc û exlaq ê olî

20-Beşa Bîstan: peywira perçe û ezayên bedenê

21-Beşa Bîst û Yekan: pûşîl û şerdeyên xwarinê

22-Beşa Bîst û Didoyan: bahsa nimêjê

23-Beşa Bîst û Sisêyan: xelasok

24-Ferheng 
Helbestvan, dawîlêanîna pirtûka xwe û tarîxa nivîsandina wê wiha dinivîse;

"Hezar bar şukur ku me berhem qedand

Me ev cemeda ser dilê xwe heland

Me pênûs gelek ser serê wê gerand

Me kir wek gulokê li hevdu gerand

Evê havîna du hezar û sisê

Meha tirmehê roja bîst $\hat{u}$ sisê

Me êvara înê roja pêncşemê

Bi kêf dawî anî li vê berhemê"

Li dawîya rûpela dawî dîyar dibe berhem li Amedê, di sala 2003an da qedîyaye (Xursî, Pêdivîyên Ol û Dînê Îslamî, r. 64).

\section{Wêranbûna Dinyayê û Avabûna Axretê}

Berhem ji 175 rûpelan pêk tê. Beşa yekem a berhemê herwiha wek destpêk hatîye nivîsandin. Berhem bi tevahî 16 beş e. Beşa duyem, sêyem û çarem mijarên berî mirinê ne. Ev jî̀ nîşaneyên berî qîyametê, nîşanên nêzî qîyametê û hilweşîna dinyayê ne. Yên mayî hemû di derbarê axretê da ne. Meriv dikare berhemê wek qîyametname yan mehşername jî bi nav bike. Weke tê zanîn di edebîyata kurdî/kurmancî da yekem mehrşername ya Feqe Reşîd e (1883-1932) (Gemi, 2018, r. 127-145). Ev jî bi hêsanî dikare bibe mehşernameya duyem. Herwiha berfirehtirîn mehşarnameya kurmancî jî ev e. Honandin û ziman serkeftî ye. Bandora Şêx 'Ebdurrehmanê Aqtepî bi her awayî di berhemê da eşkere ye. Hem ji alîyê kêş û erûzê ve hem ji alîyê honaka mijarê ve bandora Rewdu'n-Ne'îm a Şêx 'Ebdurrehmanê Aqtepî xuya dibe. Ji xwe şa'ir bi xwe jî vê bandorê vedibêje. Di dawîya berhemê da ferhengokeke kurmancî-tirkî ji layê şai'rî ve hatîye amadekirin. Di berhemên din da jî, di vê berhemê da jî nivîskar ji bo peyva "naverok" ê peyva "serecem"ê bi kar anîye.

\section{c. Dîwanên Xemkûr}

Kêm kesan di edebîyata kurdî ya kurmancî da bi qasî Xemkûr berhemên kurdî nivîsîye. Herwiha ji alîyê hêjmara dîwanan ve jî Xemkûr di nava rêzên ewilîn ên helbestnûsên kurmancî da ye. Eger em Mela Ehmedê Nalbend (1891-1963) û Cegerxwîn weke welûdtirîn du şa'irên kurmanc bihesibînin, dê Xemkûr di rêza sêyem da cih bigire. Herwiha Mela Ehmedê Palo (1920-1991) û Ferikî Usif (1934-1997) jî dibe ku bikevin nava vê koma pirberhemîyên şi’ra kurmancî.

\section{Dîwan 1 (Helbestên Olî)}

Ev dîwan ji 290 rûpelî pêk tê. Mijarên cur bi cur ên dînî tê de hene. Eşqa Xwedê, eşqa Resûlê Xwedê, alim, şêx û zanayên îslamî, mîrac, kemînên nefsê û 
gunehkarî çend mijarên sereke yên naveroka helbestên vê dîwanê ne. Bi tevahî 92 helbest di dîwanê da kom bûne. ${ }^{16}$

Ji ber mijarên naverokî yên vê dîwanê bêtir eşq û evîn e, şa'ir ji bo vê têgehê, di destpêka dîwanê da wiha dibêje:

"Eşq û evîn çi ye û çawa bayê wan li serê mirovan dixe? Bi dîtina min aşiqbûn $\hat{u}$ evîndarî ji hezkirina herî zêde çêdibe. Dema ku mirovek ji tiştekî hez bike û bêŷ̀ wî tiştî netebite, difikre $\hat{u}$ li rêya çareserîyê digere, da ku bigihêje mirazê xwe. Heke gihașt mirazê xwe aram dibe $\hat{u}$ bi hêsanî dijî. Lê ku negihêje mirazê xwe, bi kul $\hat{u}$ keder dijî. Hinek ji wan dîn dibin $\hat{u}$ bi çolan dikevin $\hat{u}$ hinek jî li ser halê xwe dibêjin û dinivîsin".

Helbestvan piştî pênase û şerha evînê, evîndarîyê jî li ser çar stûnan dadimezirîne û ji her çaran ên herî bi qîmet, li gorî dîtina xwe eşkere dike, wiha dibêje:

"Evîndarî jî̀; ji çend cureyan bi kar tê. Yek: Evîndarîya nûra Xweda û Resûlê Xweda, Du: Evîndarî ya rizgarîya millet $\hat{u}$ welat. Sê: Evîndarî ya malê dinyayê. Çar: Evîndarî ya jin û mêran. Bi dîtina min, evîndarî ya herî bi rûmet jî berî her tiştî evindarî ya nûra Xweda û Resûlê Xweda ye, $\hat{u}$ paşê jî, evindarîya azadîya millet $\hat{u}$ welat $\hat{u}$ jîyaneke bi rûmet e."

Piştî hingê şa'ir sedemên nivîsandina helbestên di vê dîwanê da wiha şîrove dike:

"Min jî weke misilmanekî kurd, bi eşqa nûra Xweda $\hat{u}$ Resûlê Xweda, $\hat{u}$ bi hesreta rizgarîya millet $\hat{u}$ welatê xwe yê bindest $\hat{u}$ belengaz, daxwazîyen dilê xwe yê bi kul $\hat{u}$ keder bi nivîsên xwe ra anîn ziman $\hat{u}$ vala kirin ser rûpelên kaxetan."

Piştî ravekirina sedemê nivîsandina helbestên xwe, şa'ir destpêka dîwanê bi hin hêvîyên xwe diqedîne. ${ }^{17}$

\section{Dîwan 2 (Buxçika Bûka Dîlgirtî)}

Navê vê dîwanê "Buxçika Bûka Dîlgirtî" ye. Sebebê navlêkirinê di destpêka dîwanê da wiha hatîye ravekirin.

"Ji ber ku bûkên kurdan tiştên xwe yên girîng $\hat{u}$ bi nirx dikin buxçikên xwe $\hat{u}$ diparêzin; $\min$ jî ev pirtûka xwe şibandîye buxçika bûka dîlgirtî û li nivîsên xwe pêçaye. Jixwe hewce nake ku em bibêjin di vê buxçika min da çi

\footnotetext{
${ }^{16}$ Ev dîwan ji layê teșeyên nezmê va di beşa sêyem (Cihê Xemkûr Di Edebîyata Kurdî Da) da, di bin binbeşa (Xemkûr Di Edebiyata Klasîk Da) ewê bê nirxandin.

${ }^{17} \mathrm{Bi}$ sedema ku di beșa sêyem (Cihê Xemkûr Di Edebîyata Kurdî Da) da ewê hemû berhemên wî werin nirxandin û ewê ji hemû berheman mînak werin dayîn me pêddivî nedî di vir da em mînaka ji dîwanan bidin.
} 
heye lewra dema ku xwendevan devê vê buxçikê vekin $\hat{u}$ li ber xwe raxin, wê bi çavê xwe bibînin ku di vê buxçikê da çi heye."

Di dîwanê da bi tevahî 99 helbest cih digirin. Piştî dîwan diqede, şa'ir weke adeteke hemû berhemên xwe di vê berhemê da jî ferhengokek amade kirîye û naveroka dîwanê xistîye dawîya dîwanê. Helbestên vê dîwanê car caran dikeve nava mijarên sîyasî jî, lê bi gelemperî li ser rewşa kurdan û belengazîya wan radiweste. Li paş her helbestekê tarîxa nivîsandina helbestê û cîyê wê hatîye dîyar kirin.

\section{Dîwan 3 (Evîna Bêmiraz)}

Ev dîwan ji 230 rûpelan pêk tê. Şa'ir ji bo vê dîwanê pêşgotinek an destpêkek nenivîsîye. Helbestên vê dîwanê nû ne. Ango bi gelemperî di salên 2015, 2016 û 2017 an da hatine nivîsandin. Dîwan ji 161 helbestan pêk tê. Di dawîya dîwanê da naveroka dîwanê li gorî alfabeya latînî hatîye dîzaynkirin. Helbestên vê dîwanê bi taybetî evîn e.

\section{Dîwan 4 (Evînname)}

Dîwan ji 226 rûpelan pêk tê. Weke ku ji navê wê jî dîyar e, dîwan helbestên evînî ne. Di serî da gelek helbest Guftûgo/Gotûbêj (Muşa'ere) ne digel "gulo". Xemkûr û Gulo avêtine ber hev, helbest bi vî awayî li ser mijara 'işqê dibuhurin. Di dîwanê da bi tevahî 164 helbest hene. Şa'ir, ji bo vê dîwanê jî destpêk an pêşgotin nenivîsîne. Di dawîya dîwanê da fihrist li gorî alfabeya latînî hatîye bicihkirin.

\section{Dîwan 5 (Ger û Geşta Min)}

Dîwan ji 149 rûpelan pêk tê. Tê de 53 helbest hene. Helbestên vê dîwanê, li gelek bajar, bajarok û gundan hatîye nivîsandin. Mijarên helbestan bi taybetî ditîn û nêrînên cuda yên helbestvan in. Bi gelemperî helbest ji çîrokekê, dîmenekê, jinenîgarîyekê pêk tê. Uslûba helbestên Cegerxwîn hatîye bikaranîn. Zimanê helbestan rewan û herikbar e. Helbestvan ji helwesta xwe ya welatparêzî û dîndarîyê daneketîye. Îmaj bi taybet di hin helbestan da xurt dibe, pir caran helbestvan hestên xwe bi cuwankarîyê xurt dike û bi mecaz û îstîareyan dixemilîne. Di dawîya vê dîwanê da ferhengokeke kurmancî-tirkî ya dirêj hatîye bicihkirin.

\section{Dîwan 6 (Kulîna Nivîna)}

Dîwan ji 231 rûpelan pêk tê. Helbestên dîwanê piranî li Amedê hatine nivîsandin. Şa'ir ji bo vê dîwanê destpêkek nivîsîye û di dawîyê da hem naverok hem jî ferhengok bicih kirîye. Şa'ir di destpêkê da bi navê Xweda û bi slavên li ser Resûlê Xweda dest bi nivîsandinê kirîye. Paşê li ser navê dîwanê radiweste, wiha dibêje: 
"Xwendevanên hêja û delal! Weke hûn jî dizanin mirov nivînan çê dike ku mirov di nav wan da razê. Ji bo vê jî mirov ji xwe zêdetir; ji bo mêvanan jî çêdike, dipêçe $\hat{u}$ dike kulina xwe. Lê ku mirov radixe $\hat{u}$ di nav da radikeve jî mirov gelek xewnên xweş $\hat{u}$ nexweş di nav wan da dibîne. Lêbelê di nav nivînê min da ti xewnê xweş nayê dîtin."

Di dîwanê da 98 helbest hene.

\section{Dîwan 7 (Tûrikê Kul û Derdan)}

Dîwan ji 214 rûpelan pêk tê. Dîwan bi tevahî ji 82 helbestan pêk hatîye. Şa'ir armanca sereke ya nivîsandina vê dîwanê wiha şîrove kirîye, di destpêkê dîwana xwe da:

"Lewre jî dilê min bi xwe bû weke tûrikê kul $\hat{u}$ derdan, tijî bû $\hat{u}$ nema derd $\hat{u}$ kul tê de hilatin. Di vê hûrnêrînê da min dît ku dilê min bi agirê kederên giran kelîya, fûrîya, birîn bû $\hat{u}$ nêm $\hat{u}$ elem girt. Lewre jî hewce bû ku ez hinek ji wan kul $\hat{u}$ kederên ku nema di dilê min da hildihatin vala bikim ser rûpelên kaxetan, da ku ji lerizandin $\hat{u}$ aramîya dilê min ê birîndar ra bibe derman."

Naveroka helbestên di dîwanê da, siruşt, evîn, newroz, derd û keserên gel, hin kesayetên taybet û navdar, hin bajar, bajarok û şina li ser wan û hîn gelek mijarên bi vî rengî hene. Dîsa wek tradisyonekê li pişt her helbestekê cih û tarîxa nivîsîna wê heye. Herwiha naverok dîsa li gorî alfabeya latînî hatîye amade kirin, ev jî divê weke uslûbeke Xemkûr a amadekirina berheman were qebûl kirin.

\section{Dîwan 8 (Welatê Wêran)}

Dîwan ji 148 rûpelan pêk hatîye. Ev dîwan cudatirîn dîwana Xemkûr e. Lewra yekem car Xemkûr di vê dîwanê da pîvaneka kîteyî, arûz û kêş danîye kêlekê û bi şêwaza helbesta nû nivîsîye. Hemû helbestên vê dîwanê modern in û bi terza serbest hatine nivîsandin. Hin caran û li hin cîyan helbest veguherîye ser cureyê ceribînê. Helbestên serbest ên vê dîwanê jî nêzîkî pexşanê hatine nivîsîn. Berovajîyê dîwanên din, di vê dîwanê da destpek, ferhengok û serecem/naverok tune. Helbestên vê dîwanê piranî van salên dawî hatine nivîsandin.

\section{CIHÊ XEMKÛR DI EDEBÎYATA KURDÎ DA}

Edebîyata miletên rojhilata navîn dikare li ser çar beşan were dabeşkirin. Edebîyata Klasîk, Edebîyata Gelerî, Edebîyata Xwemalî û Edebîyata Modern. Şi'rên edebîyata Kurdî jî li gorî vê dabeşê rûdaye. Şa'irên edebîyata Kurdî bi piranî yek alî ne, bi şêwazekê şi'r honandine. Yan şa'irên klasîk in, an şa'irên millî (Xwemalîya Kurdî) ne, yan gelerî ne û yan şa'irên modern in. Kêm şa'irên edebîyata Kurdî bi du şêwaza şi’r nivîsandine. Dema bi nêrînek giştî em li 
edebîyata Kurdî dinihêrin di navbera klasîk û modernê ${ }^{18}$ da şi'rên millî rû dane û hin nûnerên edebîyata millî hem bi şêwaza klasîk û hem bi şêwaza millî şi'r honandine. Wek mînak; Mela Ehmedê Nalbend (Xeznedar, 2018), Cegerxwîn (Cegerxwîn, 1992), ; (Îbrahim, 2016, r. 48), Tîrêj (1923-2002) (Tîrêj, 2014) bi du şêwazan; klasîk û mîllî şi’rên xwe nivîsandine. Di edebîyata Kurdî ya kurmancî da şa'îrên klasîk - modern, modern - millî, millî - gelerî, gelerîklasîk, gelerî - modern hebin jî, heta niha me hay ji wan nîne. Li gorî jêderên berdestên me şa'irên bi sê şêwaza, (klasîk - millî - modern, klasîk - modern gelerî, millî - modern - gelerî) şi’’r nivîsandine tunene.

Di edebîyata gelên rojhilata navîn da şa'irên bi sê şêwaza şi'r nivîsandine nayên dîtîn. Edebîyata gelerî ya Kurdî li kilam û stranan ava bûye. Şêwaza kilam û stranên edebîyata gelerî ya Kurdî di edebîyata gelên rojhilata navîn da nayên dîtin. Ji ber vê egerê, di edebîyata rojhilata navîn da şa'irekî bi çar şêwaza şi'r honandibe ewê neyê dîtin. Lewra di berhemên berdest da em rastî şêwaz û şa'irekî, wusa nehatin (Fesaî, 1380); (Hemdîn Şero, Bê Dîrok); (Nîkobext, 1389); (el-Qeyrewanî, 1907).

Dema em bifikirin nivîsandina şi'ra bi sê şêwaza û bi şiklekî serkeftî zor û zehmet be, emê bêjin teqez di edebîyata Kurdî da û bi taybet di edebîyata Kurdî ya Kurmancî da kesekî bi çar şêwazên edebîyatê (klasîk, gelerî, millî û modern) şi'r honandibe û berhem anîbe holê ewê neyê dîtin û li gorî jêderên berdest heta niha nehatîye dîtin, heta ku em rastî Xemkûrê Xursî hatin. Lewra Xemkûr bi her çar cûreyan helbest nivîsandîye.

\section{Xemkûr Di Edebîyata Klasîk a Kurdî Da}

Xemkûr, hem bi berhemdayina xwe nivîskarekî edebîyata klasîk e û hem ji alîyê helbestan va şa'irekî klasîk e. Pêşî emê berhemên Xemkûr ên klasîk nîşan bidin. Paşê emê li ser şi'rên wî yên bi şêwwaza klasîk hatine nivîsandin rawestin.

\section{a. Ji Alîyê Berheman Va}

Xemkûr sê berhem bi teşeya klasîk nivîsîye. Wek tê zanîn mesnewî, hem navê teşeyek edebîyata klasîk e û hem navê cureyek edebîyata klasîk e. Her sê berhemên Xemkûr bi teşeya mesnewî û bi kêşa 'erûzê hatine nivîsandin. Mewlûdname, 'Eqîdename û Mehşernameyên menzûm cûreyên berhemên edebîyata klasîk in. Xemkûr bi nivîsandina her sê cure berhemên edebîyata klasîk navê xwe di nav wêjavanên klasîk da peyîtandîye.

Xemkûr Mewlûd a xwe bi teşeya mesnewî, bi wezna erûzê, bi behra remelê 6 pengaviya mehzûf; Fa'îlatûn / fa'îlatûn / fa'îlûn û remelê 6 pengaviya meqsûr; Fa'îlatûn / fa'îlatûn / fa'îlan nivîsandiye. Herdû malikên serî ên mewlûdê ev in.

\section{"Herçî hemdê pak û paqij bê jimar}

\footnotetext{
${ }^{18}$ Mebesta me ji "Modern" ê, şi'ra nûjen, şi'ra serbest e. Ew şi'ra di navbera cenga cîhanê ya yekem û
} duyem da xwe daye der. Bê kêşan û terazû ye, lê pîveber e û newaya mûsîkîya wề heye. 
Bo Xwedayê daye ber min ev mijar

Em dixwazin qasekî bînin ziman

Mewlûda Pêxemberê Axir zeman" (Xursî, Mewlûd, r. 1)

Xemkûr, berhema xwe ya Pêdivîyên Ol $\hat{u}$ Dînê Îslamî weke mewlûda xwe bi teşeya mesnewîyê nivîsîye. Ev berhem 'eqîdename ye. Bi wezna erûzê, bi behra muteqariba 8 pêngaviya meqsûr, bi qalibê $F e^{\prime}$ ûlun / Fe'ûlun / Fe'ûlun / Fe'ûl nivîsîye. Malika pêşî ya berhemê ev e.

"Bi navê Xwudayê cîhan aferand

Bi hemdê Xwudayê hemû tişt hemand" (Xursî, Pêdivîyên Ol û Dînê Îslamî, r. 3)

Berhema Wêranbûna Dinyayê û Avabûna Axretê jî bi teşeya mesnewîyê hatîye nivîsandin. Weke cûre mehşername ye. Ev berhem jî wek berhema Pêdivîyên Ol û Dînê Îslamî bi behra muteqariba 8 pêngaviya meqsûr bi qalibê $F e$ 'ûlun / $F e^{\prime}$ ûlun / Fe'ûlun / Fe'ûl hatîye nivîsandin. Malika pêşî ya berhemê ev e.

"Bi Yezdanê ku masîwa aferand

Mûhemmed $\hat{u}$ Quran ji bo me şîyand" (Xursî, Wêranbûna Dinyayê û Avabûna Axretê, r 3)

\section{b. Ji Alîye Helbestan Va}

Xemkûr, hin helbestên xwe bi şêwaza edebîyata klasîk nivîsîye û navê xwe di nav rêza şa'irên klasîk da bi cih kirîye. Hem teşeyên nezmê wek xezel, mesnewî, murebbe' bikaranîye û hem helbestên xwe bi kêşa erûzê nivîsîye. Li jêr emê ji şi'rên klasîk mînakan bidin.

"Evîn û hesreta nûrê weke agir di dil daye

Bi derdê vê evina rij ku bimrim qey ne hêja ye?

Sivik bûn derdê dunyayê lê ya nûrê li dil maye.

Eva jandar û agirnak tenûr nav dil de dada ye" (Xursî, Helbestên Olî, r 116).

Ev xezela Xemkûr, bi erûzê, bi behra Hezec ê û bi qalibê Mefa'îlun / Mefa'îlun / Mefa 'îlun / Mefa 'îlun hatîye nivîsandin. Ev xezel bi serwaya (a, a, a, a-b, b, b, a) hatîye nivîsîn.

"Carek tu were nig min bila kes te nebînî,

Da ku ji devê yaran li me rexne ne barin

'Eşqa te bi dil min xistîye ar û rivênî,

Hêsir bi kovana te ji çavê me dibarin" (Xursî, Kulîna Nivîna, r. 25).

Ev xezela jor jî, bi serwaya ( $a, b, a, b-c, b, d, b)$ hatîye nivîsandin. Bi behra hezeca 8 pengaviya exreba mekfufa mehzûf li ser qalibê Mef'ûlu / Mefa'îlun / Mefa' îlun / Fe'ûlun hatîye honandin. 
Piranîya şi'rên wî yên klasîk bi teşeya mesnewî û bi behra muteqarib hatine nivîsandin.

"Bi navê Xwuda Xaliqê Zulcelal

Me wergirtî pênûs bi destê helal" (Xursî, Helbestên Olî, r. 156)

Ev malikên me ji nameyek Xemkûr wergirt, bi teşeya mesnewîyê hatne nivîsandin. Bi behra Muteqariba 8 pêngaviya meqsûr û li ser wezna $F e^{\prime}$ ûlun / $F e^{\prime u ̂ l u n ~ / ~ F e ' u ̂ l u n ~ / ~ F e ' u ̂ l ~ n i v i ̂ s i ̂ y e . ~}$

\section{Xemkûr Di Edebîyata Mîllî Da}

Xemkûr, piranîya helbestên xwe bi teşeya Xwemalîya Kurdî/Millî nivîsîye. Di vê teşeyê da herî zêdetir teşeya 5, 7, 11 kîteyî bikaranîye. Li jêr emê mînakên helbestên bi 5, 7, 11 kîteyî bidin.

"Xursa mey jorîn,

Warê mey şêrîn,

Têr nake nêrîn,

Ronya çave ew.

Cih ûwarê min,

Dahl û darê min,

Dost $\hat{u}$ yarê min,

Gav û çavin ew" (Xursî, Ger û Geşta Min, r. 13).

Mijara şi'rê pesnê welatê şa'ir e. Lewra şa'ir ji herêma Xursê ye. Şi'r bi 5 kîteyî hatîye honandin.

"Edirne warkî xweş e,

Tev şênahî û geş e.

Merîc çem kî navdar e,

Herdu rex jî bi dar e" (Xursî, Ger û Geşta Min, r. 33).

Sernavê vê şi'rê "Edirne-1" e. Li ser xweşikahîya bajarê Edirne û xwezaya wê hatîye nivîsandin. Şa'ir dema li bajarê Edirne gerîyaye nêrînên xwe anîye ziman. Şi'r ji 7 kîteyan pêkhatî ye.

"Gula xursa delal Heftê Xwehan e,

Spas bo wî ku ev nava'l te danî.

Bi navkî bûn hemî gundên li dorê,

Dinase ew bi du navên xuyanı̂" (Xursî, Ger û Geşta Min, r. 43).

Şa'ir, şi'ra xwe li ser taybetî û xweşikahîya gundê xwe nivîsîye. Duwazde gundê Xursê henin. Navê gundê şa'ir tenê di nava wan da ji du bêjeyan û bi du navan tê nasîn. Navê gundê şa'ir yek "Heftêxwehan"e û yek jî "Xursa Jorîn"e. Şi'r bi 11 kîteyan hatîye nivîsandin. 


\section{Xemkûr Di Edebîyata Modern Da}

Mebesta me ji helbesta modernê, helbesta serbest e. Ew helbesta di navbera cenga cihanî ya yekem û duwem da xwe daye der, bê kêş û terazû ye, lê bi pîver e, ahenga mûsîkayê tê da heye û bi hizr, hest û ramanên helbestvanî hatîye honandin.

Dîwana Xemkûr Welatê Wêran, ji helbestên nûjen/serbest pêk hatîye. Rêzên hin helbestan zêde dirêjin. Dişibihên pexşanê. Bi dirêjahîya rêzikên xwe nêzî pexşanê kiriye. Helbesta herî kin ji çar rêzikan pêk hatîye. Li jêr emê du mînakên helbestên serbest bidin.

\section{Belkî Ev Gotin}

Min baş dibîr ve bîne,

Belkî ev gotinên min a dawîn be.

Hesab bike ku ez bayê hênik bûm,

Û min li bedena te da û ji jîyana te dûr ketim.

An jî ez lehîyek ava baranê bûm

û di kuçeya ber mala te re derbas bûm.

An jî ez xewnek nîvê şevan bûm,

bi şîyarbûna te re ji ber çavên te wenda bûm

An jî ez kevok bûm

û ji nav destên te firîyam

û

ji ber çavên te wenda bûm.

Delala min

Min bo xwe meke derd

û Xemgîn nebe (Xursî, Welatê Wêran, r. 11).

\section{Ez Birîndar im}

Dilo

Çima nayê girtin?

Çima nayê girtin"li ber te" derîyê xema?

Her roj tê avdan mîna kulîlkê rexên çema dilo

Çima dilo, çima?

Û keserên te,

Keserên te her bi êş û janê hişîn in,

Qet na çimlisin û pelên xwe naweşîn in dilo.

Çima dilo, çima?

Û dengê te,

Dengê te carek bitenê ji guhê min neketin,

Lewra derd û kul û keder ji te dûr neketin dilo

Çima dilo, çima?

Û jîyana te,

Jîyana te hemû çû bi qêrîn û hawaran,

Û nalînên te ji hev dixilxilî nin lat û zinaran dilo

Cima dilo çima?

Û̉ çavên te,

Çavên te yê rizgarîyê hertim dimînin girtî û kor, 
Lewra tu ma li nav şekalan û hov derketin jor dilo

Çima dilo, çima?

Û xemên te dilo,

Xem û xeyalên te yên giran û kederê te yên kûr,

Navê min jî bi xwe re guhertin û kirin Xemkûr dilo.

Çima dilo, çimaaaaaa (Xursî, Welatê Wêran, r. 48).

\section{Xemkûr Di Edebîyata Gelerî Da}

Xemkûr, hem bi helbestên xwe û hem bi pexşanên xwe beşdarî edebîyata gelerî bûye. Bi helbest stran nivîsandin e. Di dawîya dîwana xwe Buxçika Bûka Dîl Girtî da deh (10) stran bi cih kirîye. Ji bilî stranan "Qisse" û "Pêkenî" jî nivîsîye û di nav dîwanên xwe da cih daye wan. Qisseya "Mirov û Heywan" (Xursî, Welatê Wêran, r. 106) û pêkenîya bi navê "Pêkenok" (Xursî, Welatê Wêran, r. 113) di dîwana "Welatê Wêran" da bi cih bûye. Li jêr emê cih bidin stranek Xemkûr.

\section{Ax çîyayo!}

Çîyayo te çima li me wa kir,

Te kezeba me şewitand mala me xera kir,

Te pozê xwe bilind kir serê xwe xuya kir.

Te zarokên me ji ber çavên me wenda kir çîyayo.

Ax çîyayo çîyayo çîyayo, şewityo çîyayoooo.

Ax çîyayoooo!

Cîyayo bila li me nehatana meha vê adarê.

Deşt û zozanê me geş nebana bi kulîlkên vê biharê.

Pelê zarokên me ji darê hatin xwarê.

Dilxwazekî me nema berê xwe bide çîyayê reşkê vê hewarê çîya yo.

Ax çîya yo,çîyayo, çîyayo, şewityo çiyayoooo (Xursî, Buxçika Bûka Dîl Girtî, r. 179).

\section{KESAYETÎYA Wî YA EDEBî}

\section{Ji Alîyê Tema, Mijar û Cûreyan ve}

Di şi'rên edebîyata Klasîk de temayên sereke ev in; dîn, tesewif, felsefe, şîn (mersîye), pesin (medhîye), pend (şîret) û hîkmet in. Di van temayan da hin tema û mijar ji hest û ramanên şa'ir, ji hizr û bawerîyên şa'ir dabin der jî, rewşa civakî, çandî, dînî, sîyasî ya serdema şa'ir jî kartêkirînekê li tema û mijaran dike. Di edebîyata millî da tevî hin temayên edebîyata klasîk, temayên civakî, çandî û sîyasî, hizra hişyarkirina gel, avakirina hafize û bîrewarîya civakî wek temayên sereke di şi'rên şa'irên millî da derdikevin holê. Evîn, hizr û ramanên şa'irî derbarê mijarên cûrbicûr di şi'rên serbest û gelerî da bûne mijarên şi'ran.

Xemkûr, ger şai'rekî yekalî, nûnerê edebîyatekê bi tenê bûya, me dê bikaribûya bi berfirehî mijar, tema û cureyên şi'rên wî rave bikira. Bi sedema zêdebûna mijaran, emê li jêr li ser mijar, tema û cûreyên şi’rên wî yên sereke bisekinin. 
Di şi'rên Xemkûr da evîn temaya sereke û bingehîn e. Evîn, hem bi şêweya klasîk, hem bi şêweya millî, hem bi şêweya modern û hem bi şêweya gelerî di şi'rên Xemkûr da rû dide. Di şi'rên klasîk da evîna sereke, evîna Cenabê Peyamber (s.x.1.) e. Her çend şi'rên wî yên li ser evîna Cenabê Peyamber (s.x.1.) bi şêweya klasîk hatibin nivîsandin jî, wek klasîkên me yên kevin bi têgeh, telmih, teşbîh û îstî'areyan nehatine xemilandin. Rasterast hestên xwe anîye ziman. Bi asanî tê famkirin ku Xemkûr evîndarekî Cenabê Peyamber (s.x.l.) e. Şa'ir, evîna xwe ya li ser Cenabê Peyamber (s.x.1.) wiha anîye ziman:

"Evîna şahê mehdervan,

Li min bû derdê bê derman.

Jibil mâşûq nema derman,

Ji Xemkûr re bi şîfa bî" (Xursî, Helbestên Olî, r. 29).

Di şi'rên ku bi şêwaza millî, modern û gelerî hatine nivîsandin da em evînek realîst dibînin. Şa'ir evîna xwe venaşêre û bi têgeh û mecazan nayne ziman. Bi taybet di dîwana "Evînâ Bêmiraz" û Dîwana "Evînname" yê da mijarên evînî hîn zêdetir rû dane. Di hizra Xemkûr da di dinê da derdê herî giran derdê evînê ye.

"Hûn dizanin li cîhan,

Derdê giran kîja ne?

Li gorî min evîn̂,

Derdê herî bi jan e" (Xursî, Evîna Bêmiraz, r. 54).

Hezkirîya Xemkûr Gulo ye. Gulo, hezkirîyek xeyalî ye. Di dîwana "Evînname" yê da, di 23 şi'ran da Xemkûr û Gula bi hev ra guftûgo dikin û derdên dilê xwe ji hev ra vedibêjin. Gulo jî evîndarê Xemkûr e. Geh evîna xwe ji hev ra dîyar dikin, geh hêvîya gihaştinê dikin û geh ji derdê dûrbûnîyê gazindan bi hev dikin. Li jêr ji şi'ra bi navê Bedewê, emê herdû çarînên pêşî ji guftûgoya Xemkûr û Golu wek mînak bidin.

"Xemkûr;

Beyanî baş delala min,

Şirin û çavxezala min.

Tu yî her finda mala min,

Şîyar kir dil evîna te.

Gulo;

Şîar be guh mede xewê,

Dil bide şêrîn bedewê,

Wa dixwine wek mêkewê,

Li şengalê'b evîna te" (Xursî, Evînname, r. 3).

Xemkûr nûnertîya xwe ya klasîk bi taybet di "Dîwana Olî" da derdixe pêşberî me. Di vê dîwanê da dîn temaya sereke ye. Mijara sereke evîna Cenabê Peyamber (s.x.1.) e. N'et û medhîyeyên Cenabê Peyamber (s.x.l.) cûreyên sereke 
ên vê dîwanê ne. Xemkûr di dîwanên xwe da ji bilî n'et û medhîyeyên Cenabê Peyamber (s.x.l.) gelek cûreyên edebî bikar anîye. Li jêr emê mînakên cureyên edebî pêşkêş bikin.

\section{a. Ne't}

Şi'rên li ser pesnên Cenabê Peyamber (s.x.l.) hatine nivîsîn dikevin vê kategorîye (Aykanat, 2013, r. 53) ; (Dilçin, 1992, r. 257). Bi taybet pesnên li ser gramî û mezinatîya pêxemberîyê hîn zêdetir tên dîtin. Ne'tên Xemkûr di Dîwana Olî da civîyane. Şi'rên Dil Bi Cizbê Ket, Dildar û̉ Dîlber, Gula Mûhememdî û Bi Qurban Bim mînakên Ne'tên Xemkûr in. Li jêr herdû malikên serî ên şi'ra $B i$ Qurban Bim emê mînak bidin.

"Bi qurban bim Gula Cîhan,

Li min carek bibî mêvan

Nebînin yek der û cîran

Bi qurban bim, bi qurban bim" (Xursî, Helbestên Olî, r. 27).

\section{b. Munacat}

Şi'rên, ku di naveroka xwe da neçarî, bê taqetî, poşmanî û laveyên şa'irî û li hember van mezinantî û hêza Xweda tîne ziman re Munacat hatîye gotin. Di munacatan da şa'ir daxwaza bexşandina xwe ji Xweda dike (Çelik, 2015, r. 448). Di nav şi'rên Xemkûr da du munacat cih girtine. Şi'ra Sadiq im Ellah Dibêjim û Xwestina Bexşînê dikevin cureya munacatê. Beyta serê şi' ra Sadiq im Ellah Dibêjim wiha destpêdike.

"Ez dexîlim ya Îlahî, ez bi te her bawer im, Min ji zikrê te yeqîn e, pêgirtîyê pêxember im" (Xursî, Helbestên Olî, r. 227).

\section{c. Şefa'etname}

Ji şi'rên daxwazîya mehdervanîyê ji Cenabê Peyamber (s.x.1.) dikin û naveroka malikan li ser mehdervanîya roja heşrê hatibe avakirin re Şefa'etname tê gotin. Dibe helbest seranser Şefa'etname be û dibe di helbestekê da hin malik daxazîya mehdertîyê anîbe ziman (Kardaş, 2013, r. 1903). Sernava şi'rêk Xemkûr, Daxwazîya Şefa'etê ye. Ji sernava şi'rê dixuye ku şi'r Şefa'etname ye. Herdû beytên pêşî wiha ne.

"Seyyidê min rêberê min! Xwestekim bê çare me.

Min avêt ser te reşa xwe, va li ber rewza te me.

Min li hîsabê biparêze, xwedî rabe li me.

Çavê min mane li rê ez, bende birhanek te me" (Xursî, Helbestên Olî, r.

$55)$. 


\section{d. Mi’racîye}

Şi'rên li ser Mi'raca Resûlê Xweda hatibe nivîsandin, bûyera mi'racê kiribin mijarên xwe di vê kategorîye da tên senifandin (Kınay, 2016, r. 262). Mi'racîye, dibe hem şi'rek serbixwe be û dibe berhemek serbixwe be. Şi'ra bi sernavê Mîrac hatîye nivîsandin mijara Miracê anîye ziman. Şaîr di çarîna yekem da hezkirina xwe ya li hember Cenabê Peyamber (s.x.l.) tîne ziman. Di çarîna duwem da hin hêvîyên xwe rave dike û di çarîna sêyem da dest bi mijara Mi'racê dike. Çarîna sêyem wiha ye.

"Seyyidê min rêberê min serwerê ola helîm

Tu bi fermana xudayê min giha erşê Ezîm

Ku te xwest sola xwe derxî, xwas biçe 'erşe 'ezîm

Lê Xwedayê min nehişt tu xwas biçî erşê 'ezîm" (Xursî, Helbestên Olî, r. 145).

\section{e. Mededname}

Şi'rên li ser xwestina alikarîyê amadebûne wek Mededname hatine binavkirin (Çelik, 2015, r. 450). Şi'ra Xemkûr a bi navê Ya Resulellah Meded Mededname ye. Di şi'rê da şa'ir alîkarîyê ji Resûlê Xweda dixwaze. Şa'ir ji dileva bêjeya elmeded Ya Hefadê Me Hejaran bikaranîye. Ev riste di dawîya hêmû çarînan da wek dîsgotina helbsetê hatiye bikaranîn. Destpêka Medednameyê wiha ye:

"Ez ji amed têm mêvan im,

Dil kebîb im bê eman im,

Te dermanê xwe dizanim,

Ya hefadê me hejaran" (Xursî, Helbestên Olî, r. 269).

\section{f. Cîhadname}

Sê helbestên Xemkûr ên binavê Cîhad 1, Cîhad 2 û Cîhad 3 mijarên cîhadê bi bîr tîne. Me van şi'ra wek Cîhadname bi nav kirine. Di hizra şa'ir da cîhada pêwist cîhada zanebûnî û dewlemendîyê ye. Şi'ra Cîhad 1 bi vê malike destpê dike ku hizra şa'irî jî bi me dide nasîn.

"Kafirên stemkar, kar kir û pêşde çûn,

Hogirên misilman, bo çi razane hûn" (Xursî, Helbestên Olî, r. 31).

\section{g. Hîkmetname}

Hîkmet, tiştên ji bo kiryarên herî baş û qenc werin holê re hatîye gotin (Şukr, 91, r. 28). Çi berhem û çi şi'rên li ser vê mijarê hatibin nivîsandin wek Hîkmetname tên nasîn. Şi'ra xemkûr ya bi navê Rezên Şewîtî dikeve cureya Hikmetnameyê. Di şi'rê da hîkmet bi hîkayetekê hatîye rave kirin. Malika pêşî a şi'rê wiha ye. 
"Hebû kesek dilovan, bo hejaran mihrîvan.

Xwedî rez $\hat{u}$ dewlemend, bi şivan $\hat{u}$ bi gavan" (Xursî, Helbestên Olî, r. 215).

\section{h. Remezanname}

Şi'rên mijarên derbarê meha remezanê û rojîya wê de ji xwe ra kirine mijar Remezanname nin (A. Mermer, S. Deniz, Y. Bayram, L. Alıc1, M. Eflatun, N. K. Keskin, 2014, r. 304). Xemkûr hem li ser meha remezanê û hem li ser hin rojên ôlî yên pîroz helbest honandine. Wek giramîya rojîgirtina dehikê hecîyan kirîye mijara şi'ra bi navê Giringîya Dehikên Hecîyan, şi'ra bi navê Rûmeta Şeva Qîmetbiha li ser şeva leyletu'l-Qedrê hatîye nivîsandin. Şi'ra bi ser navê Rojîya Remezanê dikeve nav cûreyê Remezannameyê. Destpêk wiha ye:

"Rojî mehek bê gemar e.

Xêrû berket jê dibare

Rojî girtin bo me kar e.

Werin vê xêr û berketê" (Xursî, Helbestên Olî, r. 218).

\section{i. Nesîhetname}

Şi'rên mijara wan pend û şîret bin ji wan ra Pendname, Nesîhetname, Şîretname hatine gotin (Çelik, 2015, r. 456). Di helbesta Dilsozîya Bi Olê Re da şîret û nesîhetan dide mislimanan. Di helbesta Dilo Bêje Şêx $\hat{u}$ Mela da nesîheta li şêx û melayan dike. Di dîwanên wî de gelek şi'r û malikên pendwarî tên dîtin. Wek mînak; di dîwana "Evîna Bê Miraz" da şi'ra Derdan Li Xwe Kom Nekin ji şîretan pêk hatîye. Malika yekem a şi'ra Dilsozîya Bi Olê Re wiha ye.

"Werin ba min gelî yar $\hat{u}$ hevalan,

Bibêjim bo we çend heb galegalan" (Xursî, Helbestên Olî, r. 85).

\section{j. Qîyametname}

Şi'rên li ser bûyer û rûdanên qîyametê dikevin bin vî navî (Güzel, 1999, r. 652). Helbesta bi navê Dawîya Dinyayê rabûna qîyametê kirîye mijar. Ji ser nava şi'rê jî mijara wê dixûye. Şi'r bi munacatê dest pê dike û paşê rewşa qîyametê rave dike. Pifkirina sûrê, rabûna mirîya ji goran û mijarên roja heşrê di şi'rê da bi cih bûne. Herdû malikên destpêka helbestê wiha ne.

"Melek ku puf sûrê bikî,

Laş û gîyan ji hev dikî

Ba û bahozê radikî,

Çîyan ji cê wan radikî" (Xursî, Helbestên Olî, r. 49). 


\section{k. 'Tyadetname}

Şi'rên di wan da şa'ir bi felekê, bayê, avê ra weke dost û hevalekî xwe bi terzek samîmî bi wan ra diaxive dikevin bin cureya 'Tyadetnameyan (Çelik, 2015, r. 461). Xemkûr di dîwanên xwe da, xwe ji cûreya 'Tyadetnameyan bê par nehiştîye. Şi'ra bi navê Bayê Hênik dikeve kategorîya 'Tyadetname ye. Di vê şi'rê da pirsen şa'irî ji bayê tê dîtin. Şi'ra bi navê Bayê Hênik dişibihe şi'ra Feqîyê Teyran (1561-1641) a meşhur Ey $A v \hat{u} A v$. Pêkane Xemkûr di bin bandora Feqî da mabe. Şi'r wiha destpêdike:

"Ya Reb çi ba ye tu didî,

Belkî tu çavan jî nedî.

Zanim ku nayê bê xwedî,

Dîyar bikî vê hikmete" (Xursî, Helbestên Olî, r. 16).

\section{l. Medhîye}

Ji şi'rên pesnê re Medhîye tê gotin. Di medhîyeyan da pesnê şah, padîşah, kesayetên mezin wek şêx, mela, şa'ir, sîyasetmedaran tên dîtin. Ji bilî van kesên, di dile şa'irî da cih girtibe, wek dost û hevalên wî jî dibin mijara medhîyeyan (Fesaî, 1380, r. 161). Helbesta bi navê Axtepe, medhîyeya li ser şêx 'Ebdurrehmanê Aqtepî û berhema wî ya giranbiha Rewdî' $n-N e$ 'îm ê ye. Helbesta bi navê Seyda Mela Ehmedê Şêx Remo dikeve nav cûreyê medhîyeyan. Destpêka şi'ra Axtepe wiha ye.

"Kete destê me pirtûkek ji ristan, Mi go qey ez ketim nav werz û bîstan" (Xursî, Helbestên Olî, r. 10).

\section{m. Mersîye}

Mersîye, bêjeyek erebî ye. Di edebîyata farisan da bi "sûgname" an "mersîye" û di edebîyata tirkan da "ağit", di edebîyata Kurdî da bi "Zêmar" hatîye binavkirin. Wek ku em dizanin mersîye bûye navê çeşnek ji helbestên edebîyata klasîk û di edebîyata klasîk a kurdî, farsi, erebî û tirkî da, helbestên li ser şînê, şîna kesên cih di dilê şair da girtibe bi vî navî hatine nasandin (Fesaî, 1380, r. 172). Şi'ra li ser mirina Celal Telebanî (1933-2017) nimûneyek ji mersîyeyên Xemkûr e. Ev şi'r di dîwana Evîna Bêmiraz da cih girtîye. Di heman dîwanê da em li ser Seydayê Tîrêj jî mersîyeyê dibînin. Mersîyeya li ser Celal Telebanî bi van malikan destpêdike.

"Mam Celal Telebanî,

Te jî serêxwe danî,

Bû mêvanê axa sar,

Serî li gorê danî" (Xursî, Evîna Bêmiraz, r 106). 


\section{n. Jînname û Xwejînname}

Jîyanname bi navê "Zendegîname", "Karnam"e" û "Tercumeê Hal" jî tê nasîn. Şa'ir ji destpêka jîyana xwe heta dema nivîsandina şi'rê wek kurte jîyana xwe dide ber çavan (Dad, 1385, r. 270-271). Di hin cûreyên Jîyannameyan da jîyana hin kesayetan piştî mirina wan ji teref hin kesan de bi şi’r tê nivîsandin. Di edebîyata Kurdî da ev cûre berhem tên dîtin (Ertekin, 2015). Xemkûr weke hin şa'iran jîyana xwe bi helbest anîye ziman. Di helbesta bi navê Rojbûna Min da em jîyannameya şa'ir dibînin.

"Sala çil û pêncan ku hat,

Roj bû yekê meha sibat.

Xwedê ji derya jîyanê,

Da dayîkek xursî xelat " (Xursî, Evîna Bêmiraz, r. 169).

\section{o. Newrozîye}

Newrozîye yan Newrozname cureyek edebî ye. Ji bo pîrozbahîyên newrozê şi'r û stranên taybet li ser girîngî û rewşa cejna newrozê hatine nivîsandin dikevin bin vê kategorîyê. Ji şi'rên bi vî rengî re Newrozîye hatîye gotin. (Ergün, 2018, r. 335) ; (Artun, 2017, r. 158) Were Em Herin Newrozê di nav şi'rên Xemkûr da mînakek e ji bo cûreyên newroznameyê. Di dîwana "Tûrikên Kul û Derdan" da jî helbestek Newrozîye tê dîtin. Her wiha di dîwana "Welatê Wêran" da şi'ra serbest a bi navê Nerwroz jî Newroznameyeke Xwemkûr e. Çarîna pêşî ji şi'ra Were Em Herin Newrozê wiha destpêdike.

"Zivistan çû dinya li me bûye bihar.

Gul û gîya şîn hatine'l ser koka xwe.

Were em derkevin tevde ji gund $\hat{u}$ war,

Herin nava gul û gîya newroza xwe" (Xursî, Buxçika Bûka Dîl Girtî, r. $160)$.

\section{p. Name}

Şi'ra ji teref şa'irî ji bo kesekî din ji bo daxwazakê, ji bo ravekirina mijarekê, ji bo çareserkirina pisgirêgekê yan ji hişyarkirin û şîretan hatîye nivîsandin bi cûreya Nameyê tê nasîn. (Deniz, 2008, r. 15). Di dîwanên Xemkûr da gelek Name tên dîtîn. Bes di Dîwana Olî da sê name hatine nivîsandin. Yek ji wan nameyan ji bo Mela Tewfîq hatîye nivîsandin. Name wiha destpê dike.

"Bi navê Xudayê sîfatên kemal,

Me pênûs bi destê xwe girtî li mal.

Me çend xet nivîsî li vê kaxetê,

Jibo yek bira yê xwe yê axretê" (Xursî, Helbestên Olî, r. 165). 


\section{q. Guftûgo/Gotûbêj}

Şi'ra ji teref du kesan ve hatîye honandin, ango du kesan şi'r avêtine ber hev ra Guftûgo tê gotin. Pêkan e ku herdû şa'ir rasteqîn bin û şi'r avêtibin ber hev, wek; Guftûgo ya Mela û Feqî (Zivingî, 1978, r. 895), û dibe yek jê kesekî xeyalî be. Şa'ir di xeyala xwe da bi hin şa'ir an kesayetan an dildara xwe ra axivî be. Di dîwanên Xemkûr da Guftûgo cihekî taybet digire. Şa'ir di xeyala xwe da bi hin kesan ra diaxive. Bi giştî 26 Guftûgo di dîwanan na bi cihbûne. Ji wan Guftûgo yan; 23 Guftûgo bi Gule ra, yek bi Goyî ra, yek bi Xak ra û yek jî bi Cegerxwîn ra ye. Mînaka Guftûgo yan li jor hate dayîn.

\section{r. Hîcwîye}

Hicwîye jî cureyek edebî ye. Di dîwanên Xemkûr da ji hicwîyeyên şexsî zêdetir, rexneyên civakî tên dîtîn. Di edebiyata farsî da ji vê cûre rexneyan ra Tenz (Dad, 1385, r. 339) hatîye gotin. Li jêr dema em kesayeta Xemkûr ji alîyê civakî da vekolînîn ewê bi berfirehî li ser vê mijarê bê sekinandin. Ji ber vê yekê, li vir em li ser nasekinin.

\section{Ji Alîyê Ziman ve}

Zimanê şi' rên Xemkûr ji zimanê şai'rên klasîk cuda ye. Di helbestên wî de berovajî şa'irên klasîk, bêjeyên farsî û 'erebî gelekî hindik in. Heta ji Xemkûr hatîye kurmancî bikar anîye. Hin bêjeyên 'erebî hebin jî, ji bêjeyan bêtir têgehên dînî ne, wek; Rehman, Rehmet, Subhan, Zikir. Ev cûre têgeh gelek caran ji bo wezna şi'rê hatine bikaranîn. Lewra em dibînin di heman malikê da wateya bêjêyê bi kurdî jî heye. Wek Mînak;

"Ji kufrê re neyar e her 'eduw we,

Musulmanan di bexşîne, 'efuw we" (Xursî, Helbestên Olî, r. 42).

Wek xalek sereke di şi'r û dîwanên şa'irên klasîk da bêjeyên razber zêde tên dîtîn. Xemkûr xwe ji bêjeyên razber dûr kirîye. Li dewsa bêjeyên razber bêjeyên şênber bikar anîye. Bi vî rengî ji alema şi'rê ya razber derdikeve û dinya û hestên xwe bi bêjeyên şênber û halê rasteqîn vedibêje. Teşbîh û îstîareyên şi'rên wî bi sedema bêjeyên şênber çêjek taybet dide mirovan. Bi van taybetîyên xwe dibe şa'irekî realîst. Wek Mînak:

"Bê zar û girtî û dîl im, li nav koma neyara

Cerg $\hat{u}$ dev û levê min, ziwa bûne'j hewara

Jîna min hemî borî, li ber hêt $\hat{u}$ dîwara

Ta kengî dê rizgar bim, ji destê dilgemara" (Xursî, Evînname, r. 10).

Xemkûr ji bedêla mezmûn û têgehên edebîyata klasîk ku bi piranî ji bêjeyên erebî û farsî pêk tên têgehên Kurdî xistîye cihê wan. Wek mînak; ji dêleva Çeşmên Cadû û Reştûz ê Awirên Mêrkuj, ji dêleva Xeram ê Meş Qitik û ji dêleva 
Dêm ê Hinark bikarhatîye. Bi vî şiklî hem ji helbestvanên klasîk vediqete û hem têgeh û teşbîhên resen çêdike.

Di şi'rên Xemkûr ên ku dikevin qada edebîyata millî, modern û gelerî da zimanê rojane hîn bêtir dixûyê. Xemkûr zimanekî sivik bikaranîye. Ziman, xwerû û vekirîye. Ji axaftina rojane ya gel hatîye wergirtin. Ji ber vê yekê şi'rên Xemkûr bi hesanî tên fêmkirin. Em ji edebîyata millî mînakekê bidin.

"Porê min tev bû hirî

Temen borî bi girî

Lewre kerên bê terî

Ketin bexçê bi herî.

Bexçe bû gêra kera,

Cî me nema'l van dera,

Em belav bûn her dera,

Ta Ege û Marmara" (Xursî, Ger û Geşta Min, r. 47).

Ji alîyê kurmancî va zimanê wî dewlemend e. Hin bêjeyên di nav gel da kêm tên axaftin di şi'rên wî da tên dîtin. Wek mînak; ji bo Edebê Pûşîl, ji bo Sìyasetê Ramyarî û ji bo Terbîyeyê Şerde bikar anîye. Ev jî, bûye dewlemendîya zimanên şi'rên wî. Armanca wî ya sereke bi vê şêwazê pêşxistina zimanê Kurdî ye. Ji bo pêşxistina zimanê Kurdî û belavkirina bêjeyên Kurdî hilbijartinek enqest tê dîtîn.

Nivîsandina ferhenga di dawîya dîwanan da xalek girîng e, hem ji bo famkirina helbestan û hem ji bo pêşketina ziman. Dema dîwan an dîwançe tên çapkirin, ji teref weşanxaneyan an ji teref amadekaran va, ferheng li dawîya wan tên bicih kirin. Carînan jî di dawîya rûpelan da wek jêrenotan wateyên bêjeyan tên dayîn. Bi taybet ev ferheng ji bo bêjeyên bîyanî ne. Lê Xemkûr hem wî bi xwe ferhengên şi'rên xwe amade kirîye û hem ferhenga wî ji bo bêjeyên Kurdî ne. Ev taybetî di nav şa'iran da nayête dîtin. Bi vî rengî hem bi şi’rê xwe û hem bi ferhengên xwe yên di dîwanên xwe da xebatek girîng ji bo bikar anîn, fêrbûn û pêşketina zimanê Kurdî kirîye.

\section{Ji Alîyê Civakî ve}

Xemkûr dilsozekî civakê ye. Dilsozîya wî ji du hêlan ve dikare bê vekolîn. Yek, alîyê dînî û yek alîyê sinc û çandî. Xemkûr, kesayetekî alim û zana ye. Di medreseyan da xwendîye. Haya wî ji bîr û bawerî û pêdivîyên dînî heye. Kiryarên tên kirin û gotinên tên gotin ji bo dîn guncav in an dijî dîn in, bi asanî dikare ji hev veqetîne. Bi zanebûna xwe û bi bîr û bawerîyên xwe, şêx û melayan rexne dike. Ev rexnekirin ne dijbertîya mela û şêxan e. Lewra em dibînin pesnê hin şêxan jî daye. Rexneyên wî li ser kiryar û gotinên dijî dîn, bîr û bawerîyên ne li gorî dîn û li ser çewtî û xwarîyên li ser navê dîn tên kirin hatine kirin. Di Şi'rek xwe da poetîka xwe ya rexneya li hember şêx û melayan wiha tîne ziman: 
"Bibê; rexnê me bo yên xapînok in

Pirêza wan ne pak in pêkenok in

Ne bo şêx $\hat{u}$ melayê rind $\hat{u}$ pak in

Di nav gel de diîsin wek mirak in" (Xursî, Helbestên Olî, r. 13).

Di şi'ra Şêxê Nexwendî da derbarê şêxên nexwendî, kesên ku agahîya wan ji dîn û tesewifê tuneye, bi cil û bergên xwe gel dixapînin wiha dibêje:

"Zatek me dî tac li serî

Çav û birû tev kilkirî

Gopal li dest rîh şehkirî

Qaşo şêxê terîqetê.

Kêfa li şêx li Mîr tune

Çav dilîzin mîna cin e

Keramet $\hat{u}$ xwendin tune

Kes nabîne vê sosretê" (Xursî, Buxçika Bûka Dilgirtî, r. 142).

Ji bo şêx û melayên bi 'ilmê xwe kiryarên xwe dikin, ji civakê ra rêbertîyên dikin, peywirên xwe bi cih tînin pesindarîyê dike. Ev yek bi me dide zanîn ku rexneyên wî li hember kiryar û gotinên şaş û çewt in. Wek Mînak:

"Şêx Maşûqê weke gul

Barê giran hilda mil

Jibo Xemkûrê xursî

Bû dermanê dilê kul" (Xursî, Evîna Bê Mİraz, r. 18).

Li ser çewtî û xwarîya since, dijî dîn û civakê gilî û gazinên xwe anîye ziman. Bê şermî û bê fedîtî, belavbûna tolazî û nemabûna namûsê gilî û gazinên sereke ne. Li ser vê rewşê nêrînên xwe yên li bajarê Antalya wiha ristîye:

"Gelek jê xort $\hat{u}$ qîz in

Li nav derya dilîzin

Nîne exlaqên olî

Lê pirin tog $\hat{u}$ tolî

Hemî ne ku bi mahr in

Lê wek maran bi jahr in

Rexên derya xîz $\hat{u}$ tav

Keç û xort tev diçin nav

Nêr $\hat{u}$ mê pev diarin

Agir li wan dibarin

Yek dibe dîk yek mirîşk

Çîpan li hev dikin îşk 
Misilman in, kafir in

Ji hev nayên naskirin" (Xursî, Ger û Geşta Min, r. 3).

Xemkûr piştî ku rexneyên xwe dike, çareserîya pirsgirêkan jî destnîşan dike. Çewtî û şaşî bi çi reng û şêwazê pêwist e ji holê bên rakirin, li gorî çanda gel tîne ziman. Di şi'ra Jinika Parsek da parskirina jinan rexne dike. Bi vê rewşê, bi parsektîya jinek ciwan gelek xemgîn dibe. Piştî rexneyên xwe çareserîya pisgirêkê nişan dide.

"Weke wê pirin, parsek $\hat{u}$ gerok

Ka em bi pirsin, çîye naverok

Bi malbatên xwe, ku ew netirsin

Dê ew bêxîret, ji kê bitirsin

Divê ku malbat, bibin yek li wan

Weke rihsitîn êrîş bikin wan

Bigrin, girêdin, destê wan bi ben

Heta wan bikin pepûk û reben

Jinikê wan jî, ji wan bistînin

Ta sozek bi cî, ji wan bistînin

Nigê wan têkin, cihekî asê

Da ku jinên xwe, neşînin parsê

Çima dê jinik, bi pars $\hat{u}$ pûsê

Xwedî kin mêrên, dûrînamûsê

Ber bi xebitin, çi kar bi dest ket

Çi pir çi hindik, ji Xwedê berket" (Xursî, Ger û Geşta Min, r. 64).

Xemkûr, ji civakê ne dûr e. Hemû rewş û bûyerên di serê civakê da derbas dibin çi dîrokî, çi sîyasî û çi çandî şopandîye û kirîye mijarên şi'rên xwe. Nezanîya gel, hejartîya millet, nexwendin, bêtifaqî, bindestîya jar û xizana, zordestîya çîna dewlemendan, mafên jinan, Komkujîya Helepçeyê û erdhêja Wanê rengên xwe didin malikên Xemkûr. Li ser erdhêja Wanê di şi'ra bi sernavê Karesata Wanê da, malikên xwe wiha dirêse:

"Werin bibinin, şarê Wana min

Hûnê nas bikin, hemû jana min

Karesata hat, serê wana min

Dil hemî sotin, bê yên stemkar" (Xursî, Buxçika Bûka Dilgirtî, r. 82). 


\section{Encam}

Helbet ev xebat di çarçoveya nivîsarekê de hate amade kirin. Loma bi tefasîl derfet tune ku wesf û taybetîyên helbesta Xemkûr bi hûrgulî were dayîn. Bi vê nivîsarê qesta me ya sereke bi hemû alîyan û bi kurtasî nasîn û danasîna Xemkûr û berhemên wî bû. Helbet em di wê bawerîyê da ne ku divê xebatên piralî û lêkolînê li ser vî helbestvanî were kirin. hêvî heye ku ev gotar bibe pêngaveke biçûk ji bo xebatên fireh.

Hemû berhemên Xemkûr bi kurdî/kurmancî ne. Ev jî berovajî tradîsyona 'alimên kurdan e. Lewra bi gelemperî helbestkarên kurd ên klasîk bi hin zimanên din jî nivîsandine.

Xemkûr di vê serdemê da, bi zimanekî sivik û rojane û klasîk şopînerekî Cegerxwîn û Tîrêj e ku ew jî pişta xwe didin Melayê Cizîrî, Feqîyê Teyran û Ehmedê Xanî.

Rûpelên berheman ên ku me di nava nivîsarê da dane hemû di forma A4ê da hatine amadekirin. Helbet dema ku bêne çapkirin, hêjmara rûpelan dê zêdetir bibe.

Xemkûr xwestîye ku kurdî di her qadeke jîyanê da were bikarhatin. Loma wî Telqîna Mirîyan nivîsîye û ev telqîna xwe li ser gelek mirîyan jî xwendîye.

Xemkûr him bi awayê pexşan û him nezm berhem nivîsîye. Di herdu cureyên nivîsînê da jî serkeftî bûye, lê di helbestê da bêtir şareza ye.

Xemkûr xwedîyê 'eqîdenameyeke menzûm e ku tradisyona vê cureyê digihije Ehmedê Xanî. Gelek 'alimên kurdan bi vê cureyê berhem nivîsandine. Xemkûr jî xwe bêpar nehiştîye.

Xemkûr xwedîyê mewlûdeke menzûm û xweser e ku serkirdeyê vê cureyê di edebîyata kurdî da Melayê Bateyî ye. Gelek 'alimên kurd bi vê cureyê berhem nivîsandine. Xemkûr jî xwe bêpar nehiştîye. Lê şêwaza Xemkûr şêwwazeke nû ye, heta ku jê hatîye xwe ji peyvên bîyanî dûr xistîye. Xwestîye bi zimanê rojane yê gel binivîse û nîşan daye bi vê helwestê uslûba nezmê jî têk naçe.

8 dîwanên Xemkûr hene. Bi vê hecmê di edebîyata kurdî da pir mînak tune ne. Eger em Cegerxwîn û Mela Ehmedê Nalbend jê derxin, Xemkûr dibe sêyem kesê ku xwedî pir-dîwanên kurdî ye.

Hemû berhemên Xemkûr li ber destê wî ne, yek jî heta niha nehatîye çapkirin.

Di berhemên dinî-didaktîkî da bi taybet di berhema Pêdivîyên Ol û Dînê Îslamê dahelbestvan di bin bandora Şêx 'Ebdurrehmanê Aqtepî da maye.

Sîstema amadekirina dîwanên Xemkûr, sîstemeke têkûz e. Naveroka helbestên xwe amade kirîye û li gorî alfabeya latînî hemû helbest rêz kirine. Di gelek berhemên xwe da jî ferhengoka kurmancî-tirkî amade kirîye. 
Helbestên sîyasî ango helbestên di xizmeta têkoşîna kurdan da komeke girîng digire. Xemkûr gelek caran helbesta xwe xistîye xizmeta bawerî û ramana xwe ya dinyewî.

Helbestên Xemkûr nerm in. Ango Xemkûr di helbestê naqîre. Şayik û bi hurmet tevdigere. Mijar çiqas tund be jî ew bi dilnizmîyê nêzîkî mijarê dibe û zû bi zû pênûsa xwe ya nazik hêrs nake. Bi vî uslûba xwe ya nerm ji Cegerxwîn vediqete.

Em dikarin bêjin Xemkûr, di pexşanê da uslûbeke sirûştî, rojane, gelane û xweser heye. Ji bo berhemên menzum-dîdaktîkî bandora Aqtepî û Bateyî eşkere ye. Di helbestan da jî Cegerxwîn û Tîrêj du kes in ku zêdetir bandor li ser Xemkûr kirine.

\section{Çavkanî}

A. Mermer, S. Deniz, Y. Bayram, L. Alıc1, M. Eflatun, N. K. Keskin. (2014). Üniversiteler İçin Eski Türk Edebîyatına Giriş. Ankara: Akçă̆ Yayınları.

Artun, E. (2017). Din̂̂ - Tasavvufi Halk Edebiyatı (Edebiyat Tarihi/Metinler). Adana: Karahan Kitapevi.

Aykanat, T. (2013). Cevrî Dîvân'1 Örnekçesinde Edebî Türler. A. Ü. Türkîyat Araştırmaları Enstitüsü Dergisi, Sayı 50, Erzurum, 47-64.

Cegerxwîn. (1992). Kîme Ez. İstanbul: Deng.

Çelik, H. (2015). Bendi Mustafa Baba Divaninda Edebi Tür ve Tarzlar. Uluslararası Türkçe Edebîyat Kültür Eğitim Dergisi Sayl: 4/1, 443-464.

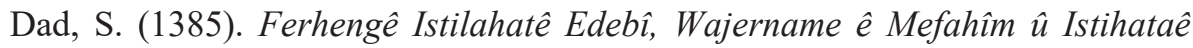
Edebî, Farsî û Ewrûpaî. Întîşaratê Morwarîd: Tehran, Îran.

Deniz, S. (2008). Kadızâde Mehmet İlmî'nin Sultan IV Murad İçin Yazdığ1 Duânâme'si. N. Öztoprak içinde, Divan Edebiyatı Araştırmaları Dergisi 1 (s. 9-40). İstanbul: Dev.

Dilçin, C. (1992). Örneklerle Türk Şiir Bilgisi. Ankara: Türk Dil Kurumu Yayınları sayı 517, 2, Baskı, Türk Tarih Kurumu Basımev.

el-Qeyrewanî, İ. R. (1907). el-'Umdetû Fî Mehasîniş-şi'rê we Adabîhî. Qahîre: Daru's-Se'adet.

Ergün, Z. (2018). Newroz û Cureyê Newroznameyê di Edebîyata Kurdî ya Nû de. Dîl Bilimleri (Klasik Sorunlar-Güncel Tartışmalar) (s. 330-345). Mardin: Mardin Artuklu Üniversitesi Yayınları.

Ertekin, M. Z. (2015). Bîyografîyeke Menzûm-Siltan Şêxmûs (Metn û Lêkolîn). Van: Lorya.

Fesaî, R. M. (1380). Enwa'ê Şi'rê Farisî. Şîraz, Îran: Întîşaratê Nuwêd.

Gemi, A. (2018). Çend Agahî Derheq Jiyana Feqe Reşîd û Sirru'l-Mehşer a Wî de. Nûbihar Akademi, h 9, r 127-145.

Güzel, A. (1999). Dinî-Tasavvufî Türk Edebiyatı El Kitabı. Ankara: Akçağ.

Hemdîn Şero, I. S. (Bê Dîrok). Wêjeya Kurdî-Amadeyî 3. Sûrî: Desteya Perwerde û Fêrkirinê. 
Îbrahim, Î. (2016). Rengvedana Dîroka Kurdî Di Helbestên Cegerxwîn De. Mardîn: Zanîngeha Mardîn Artukluyê, Enstîtûya Zimanê Zindî yên li Tirkiyeyê, Şaxa Makezanista Ziman û Çanda Kurdî, Teza Lîsansa Bilind.

Kardaş, S. (2013). Cem Sultan'ın Cemşîd ü Hurşîd Mesnevisinin Edebi Tarzlar Açısından Değerlendirmesi. Turkish Studies - International Periodical For The Languages, Literature and History of Turkish or Turkic Volume 8/1, 1899-1909.

Kınay, N. (2016). Edebî Türler Ve Tarzlar Bağlamında Lârendeli Hamdî’nin Leylâ İle Mecnûn Mesnevisi Üzerine Bir İnceleme. Erzincan Üniversitesi Sosyal Bilimler Enstitüsü Dergisi (ERZSOSDE) ÖS-III, 257-270.

Newayî, M. (2018). Mela Elîyê Teremaxî (sedsala 16-17), Tesrîfa Teremaxî Yekemîn Gramera Kurdîya Kurmancî-. İstanbul: Nûbihar.

Nîkobext, N. (1389). Tehlîlê Şi'rê Farsî. Tehran: Semt.

Şukr, E. (91). Hîkmet Der Nîgahê Mufessiranê Quran û Feylesofan. Fesilnameê Felsefe ve Kelamê Îslamî Ayîneê Me'rîfet, Danişgahê Şehîd Behiştî, Tabistan, Iran, 27-46.

Tîrêj. (2014). Dîwan (Xelat-Zozan-Cûdî). Stenbol: Peywend.

Xeznedar, M. (2018) Ehmedê Nalbend, Ji Soranî Werger: Zîya Avcı, Kovara Nûbihar, Havîn, Hejmar 144, 44-48.

Xursî, X. (Destxet). Dîwan-1- Helbestên Olî. Berhema Neçapkirî.

Xursî, X. (Destxet). Dîwan-2- Buxçika Bûka Dîlgirtî. Berhema Neçapkirî.

Xursî, X. (Destxet). Dîwan-3- Evîna Bêmiraz. Berhema Neçapkirî.

Xursî, X. (Destxet). Dîwan-4-Evînname. Berhema Neçapkirî.

Xursî, X. (Destxet). Dîwan-5- Ger û Geşta Min. Berhema Neçapkirî.

Xursî, X. (Destxet). Dîwan-6- Kulîna Nivîna. Berhema Neçapkirî.

Xursî, X. (Destxet). Dîwan-7- Tûrikê Kul û Derdan. Berhema Neçapkirî.

Xursî, X. (Destxet). Dîwan-8- Welatê Wêran. Berhema Neçapkirî.

Xursî, X. (Destxet). Mewlûda Kurdî. Berhema Neçapkirî.

Xursî, X. (Destxet). Pêdivîyên Ol ĥ Dînê Îslamî (Eqîda Îmanê). Berhema Neçapkirî.

Xursî, X. (Destxet). Pirs î Bersivên Ol û Dînê Îslamê. Berhema Neçapkirî.

Xursî, X. (Destxet). Telqîna Mirîya. Berhema Neçapkirî.

Xursî, X. (Destxet). Wêranbûna Dinyayê û Avabûna Axretê. Berhema Neçapkirî.

Zivingî, M. E. (1978). El- 'Iqdu'l-Cewherî fî Şerh-î Dîwan'iş-Şeyxi'l Cezerî.

Dimeşq: Çapê Duwem, Metbe'etî Sebah. 


\section{Pêvek}

1- Destpêka beşa yekem û beşa dawî ji Mewlîd ê

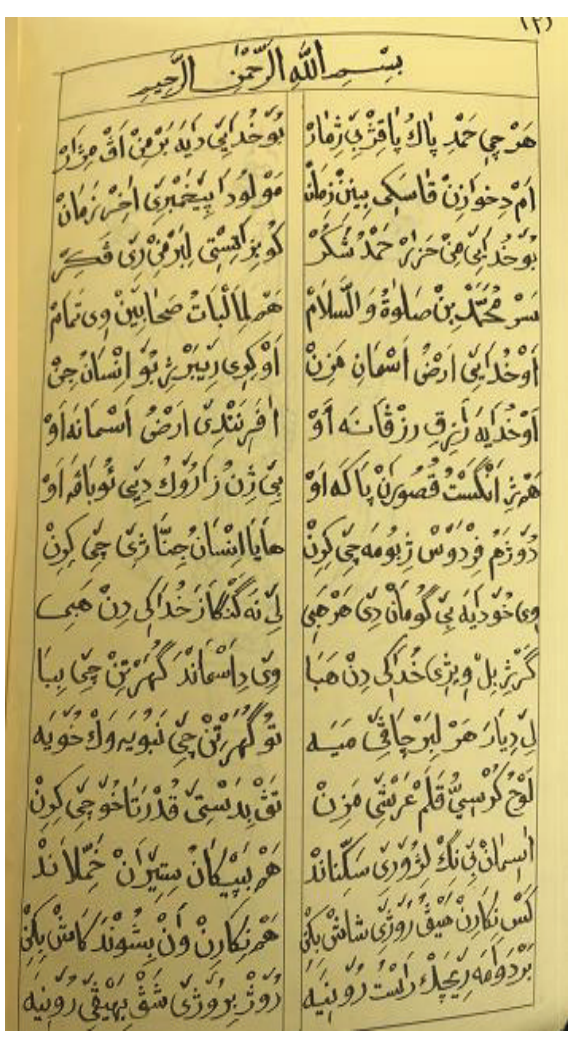

\section{SEKNA RÊZGİRTINÊ}

Tu bi xêr hat, fermandarê dewletê, Tu bi xêr hat, bendikarê ummetê.

Tu bi xêr hat, destegirê birçĩyan,

Tu bi xêr hat, rûmetdarê sêwî̀yan,

Tû bi xêr hat, yekemînê muslîman.

Tu bi xêr hat, ronîya dîn û îman.

Tû bi xêr hat, ya îmamê enbiya,

Tu bi xêr hat, dawîdarê enbiya.

Tu bi xêr hat, dijberê zilmdarî yê.

Tu bi xêr hat dijî koledarî yê,

Tu bi xêr hat, ronîya her tarî yê,

Tu bi xêr hat, pêşengê rizgarî yê.

Tu bi xêr hat, ey Resûlê rind û çak,

Tu bi xêr hat, rêberê vî dînê pak.

Tu bi xêr hat, dawîya peyxamberan,

Tu bi xêr hat, rû nehişt bo peykeran.

Tu bi xêr hat, dijberê serdestîyê,

Tu bi xêr hat, dijberê zordestîyê. 


\section{2- Rûpelên pêşî û dawî ji Pêdivîyên Ol $\hat{u}$ Dînê Îslamî}

\section{(Eqîdename)}
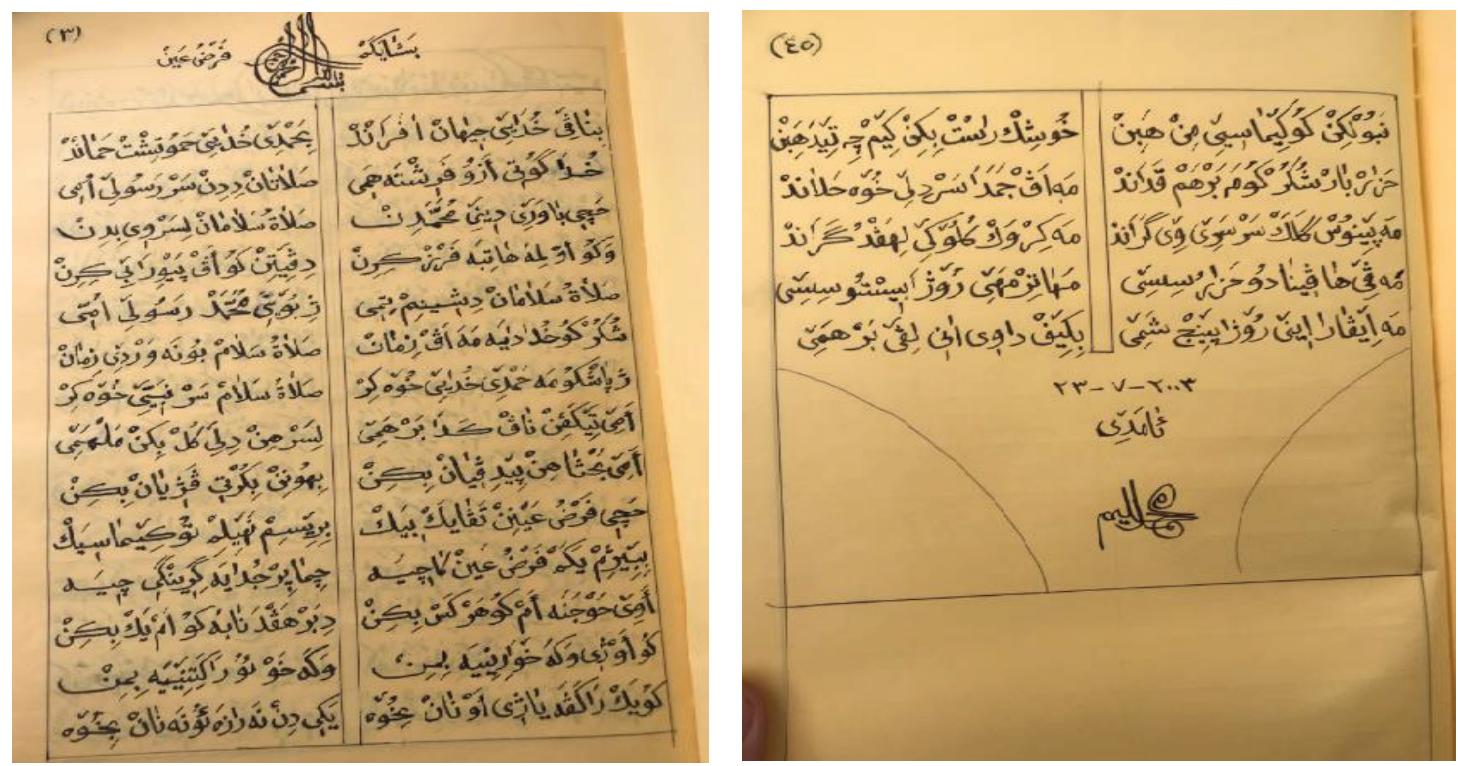

TELQINA MIRIYAN

BISMILLAHIRREHMANIRREHÎM

Elhemdu lillahî rebbil'âlemîn, wesselat û wesselamû Éla xeyrî xelqîhî Mûhemmedin we ela alihî we sehbihî ecmeîn.

Ya keça yan jî kurê filan kes û filan kesê! tu zanibe ku ji Xwedayê dilovan pêve tu kes zindî namînin, hemû kes dimirin, tunne dibin û çavên xwe li jiyanê digirin. Lê mirina herî bi rûmet ewe ku, mirov xwe ji nebaşiyan bi parêzin û xwe ji çûyina bihiştê re amade bikin. Lewre girîngîya jiyana dinyayê, jibo amadekarîyên axretê ye.

Ya keç yan jî kurê filan kes û filan kesê ! Xwedayê dilovan em ji axê afirandine û ewê dîsê me bimirîne bike êmê kurm û kêzên binê vê axê û ewê dîsê me ji gorên me rake û hesabê tiştên ku me li dinyayê kirine bi me re bibîne.

Ya keç yan jî kurê filan kes û filankesê!(3-caran) tu bi destûra Xwedê, bi xêr û bereketa navê Xwedê, li ser bawerîya bi Xwedê û li ser navê Ummet'a Mûhemmed élehisselat û wesselam ji nav me vequtiya ye û derbasî mala xwe ya yekemin a Axretê bûye.

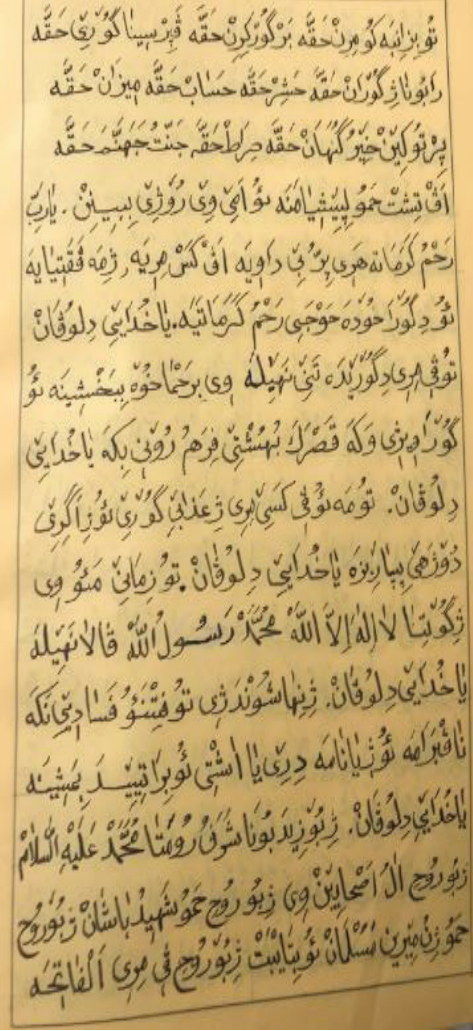

The Journal of

Mesopotamian Studies

Periodical Journal for Kurdish, Arabic and Syriac Studies

Vol. 4/2 Summer 2019 
4- Helbesta yekem ji Dîwana Olî û rûpelê dawî ji destxeta Dîwanê

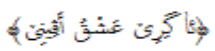

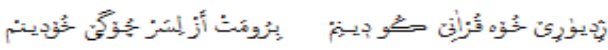

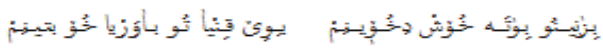

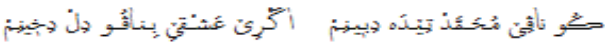

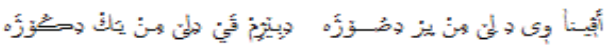

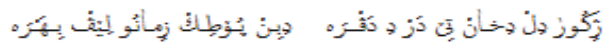

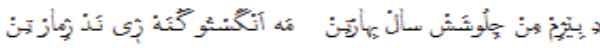

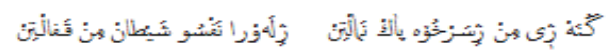

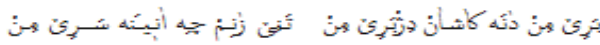

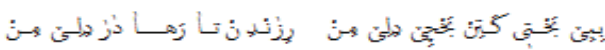

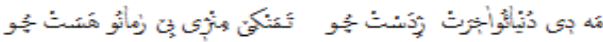

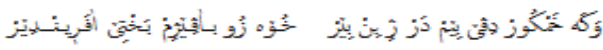

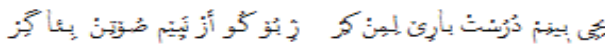

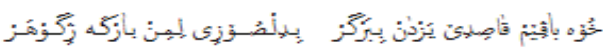

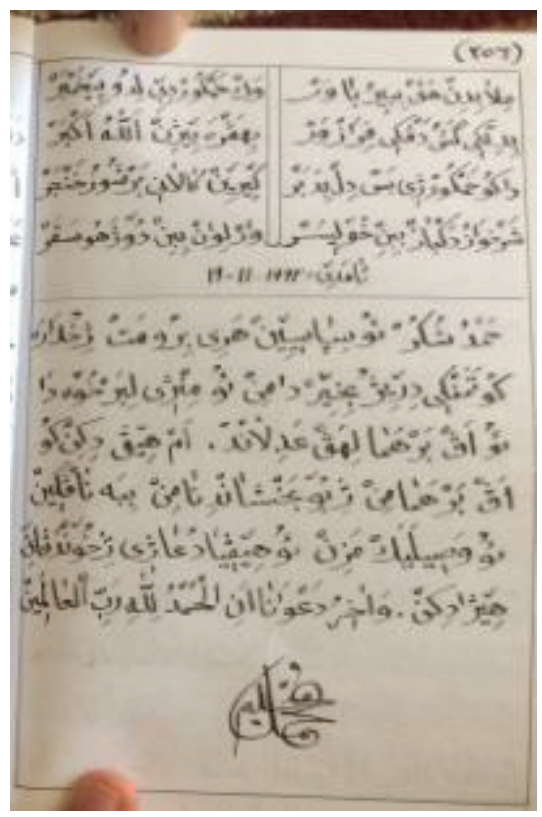

\section{5- Rûpelê pêş̂̀ û dawî ji Wêranbûna Dinyayê û Avabûna Axretê}

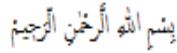

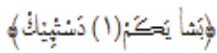

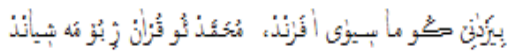

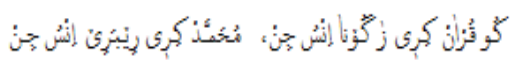

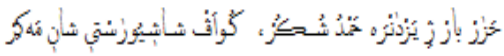

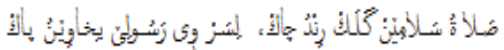

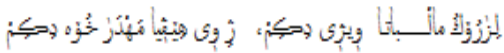

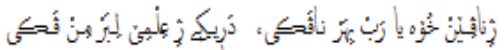

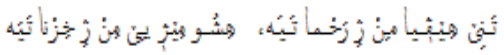

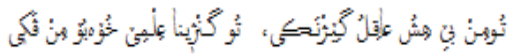

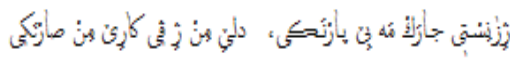

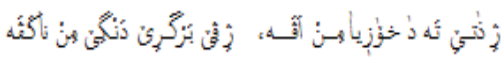

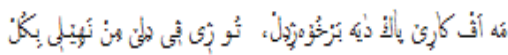

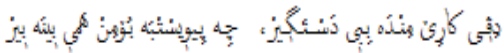

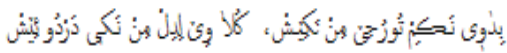

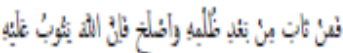

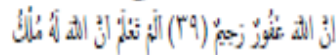

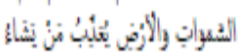

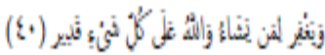

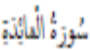

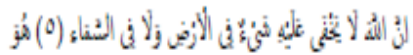

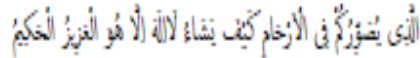

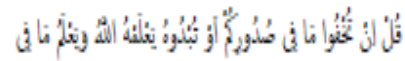

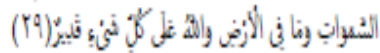

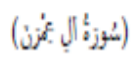

"İnna lillahî we inna îleyhî raciûn-Hesbîyellahû we nî́mel wekil, Ni'mel mewla we ni'mennesîr.

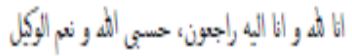

$$
\begin{aligned}
& \text { نعم الملو و نم التصري }
\end{aligned}
$$


6- Bergê Dîwanê û dawîya ferhengê ji dîwana Evina Bê Miraz

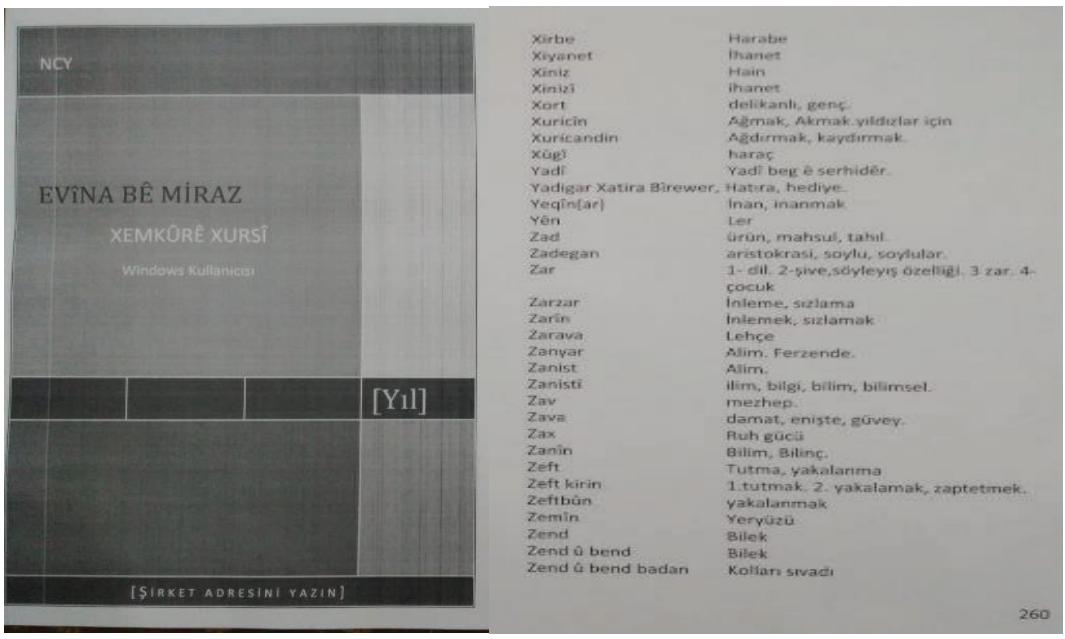

7- Helbesta yekem û rûpelê dawî ji dîwana Evînname yê

\section{BFDEWÊ}

Bevant bas delal a min

șarin uf cavxezal a min.

Tu vi her finda mal a min,

Slvar kir dit evina te

Xemikôt

Siyarbe gub mede xewe.

Det bide serin bedewt.

Wa dixwine wek mekewé,

Li sengalêt b evina te.

Gulo

if songal ef $f$ wi war it

Pevam da min te évar i

Limin kir ro/ seva tari,

Meva esq Gevina te

Xemkär

Tu dilidar' ki birèzan

Sevadé benoè kozan

Evindari, ne erzan i,

Ku derman kim birina te.

Sirin thire dewa nabe.

gi dermanan hesarn nabe

Tu ray a care ie nabe

Ai bil pervek bi vina te

Xemkîr

Delalo bo te soxdarim,

Bi esqa te birindarim

Sev 0 rojan hewesdarim.

Bi kovana evina te

Guls

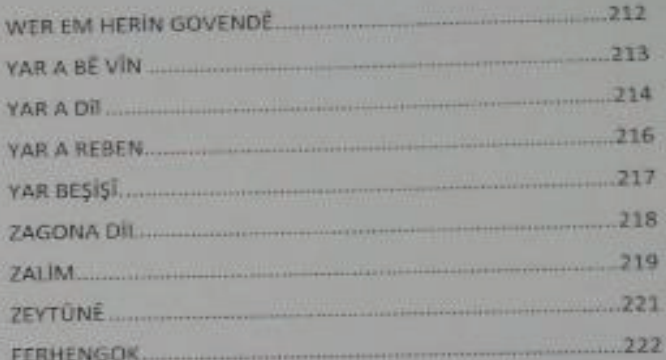

FPRHENGOK 
8- Helbesta yekem û rûpelê dawî ji dîwana Ger û geşta Min

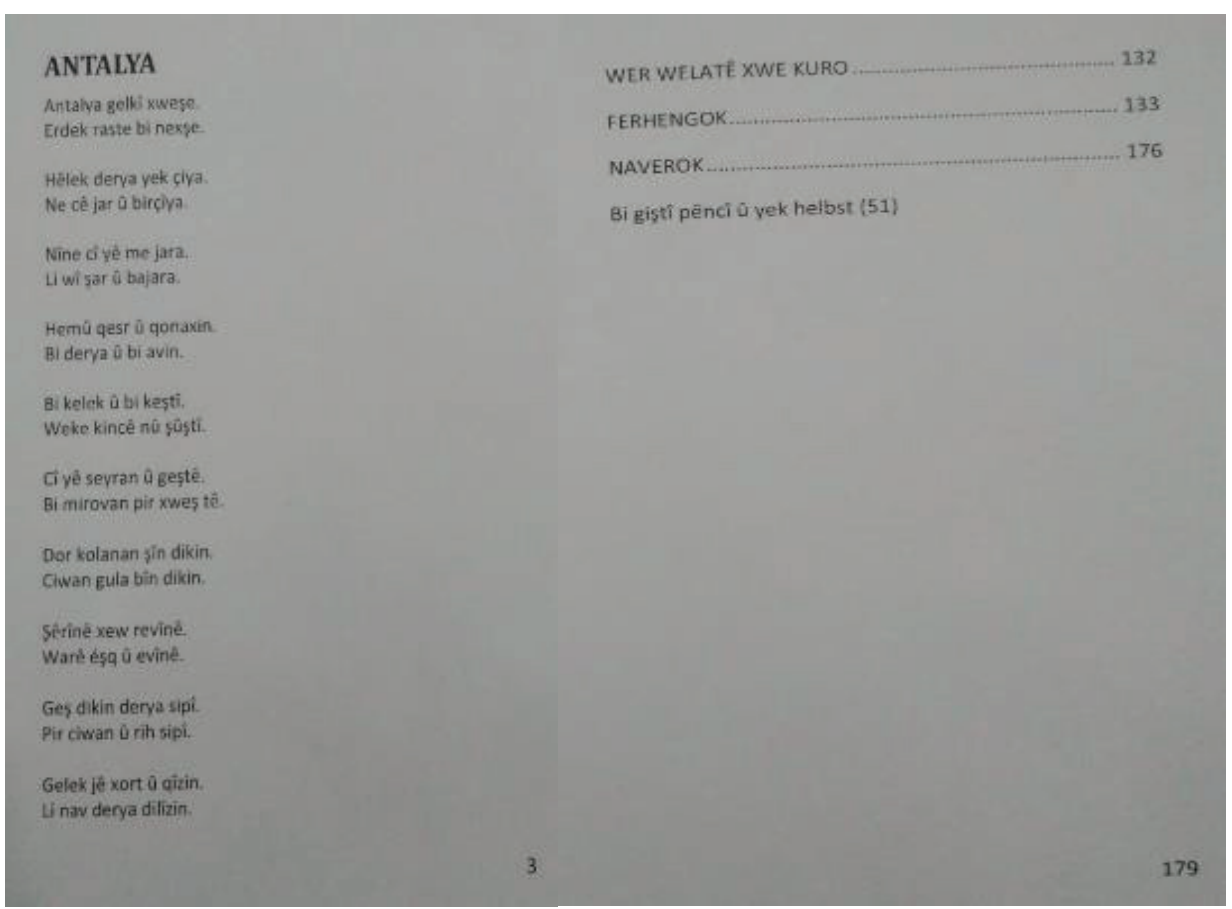

9- Berg û dawîya naveroka diwana Kulîna Nivîna

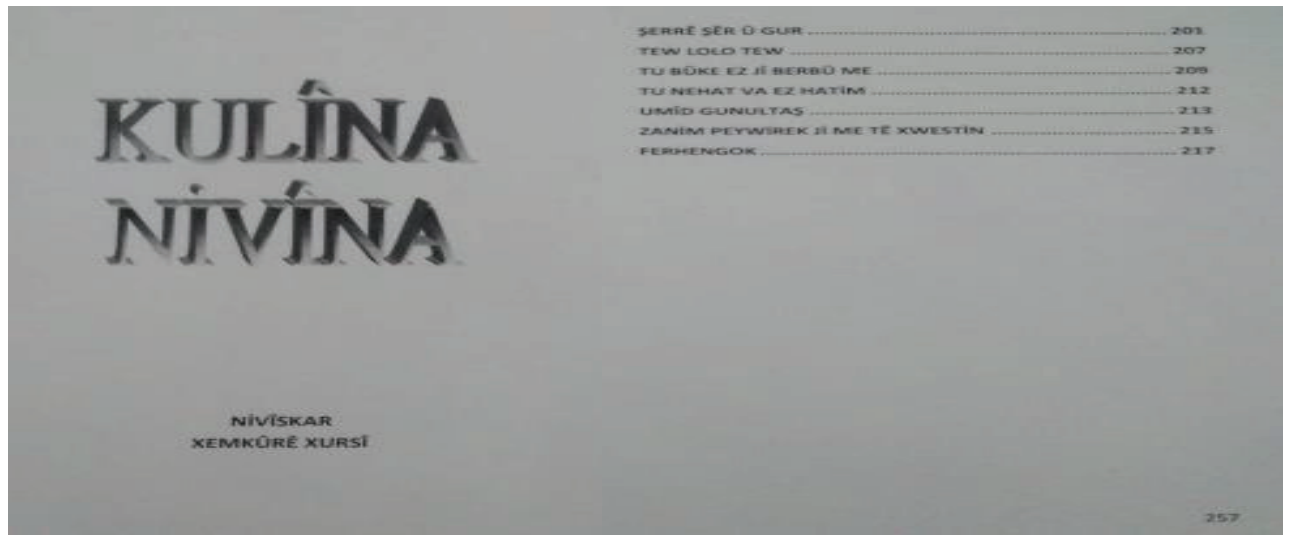


10- Berg û helbesta dawî ji dîwana Welatê Wêran

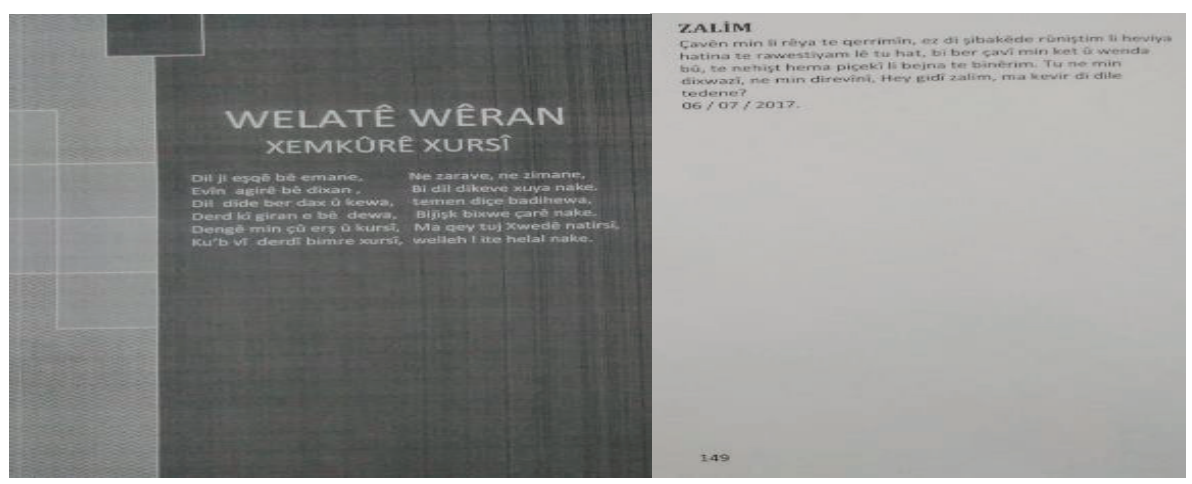

11-Berg û dawîya ferhengokê ji dîwana Buxçika Bûka Dîlgirtî

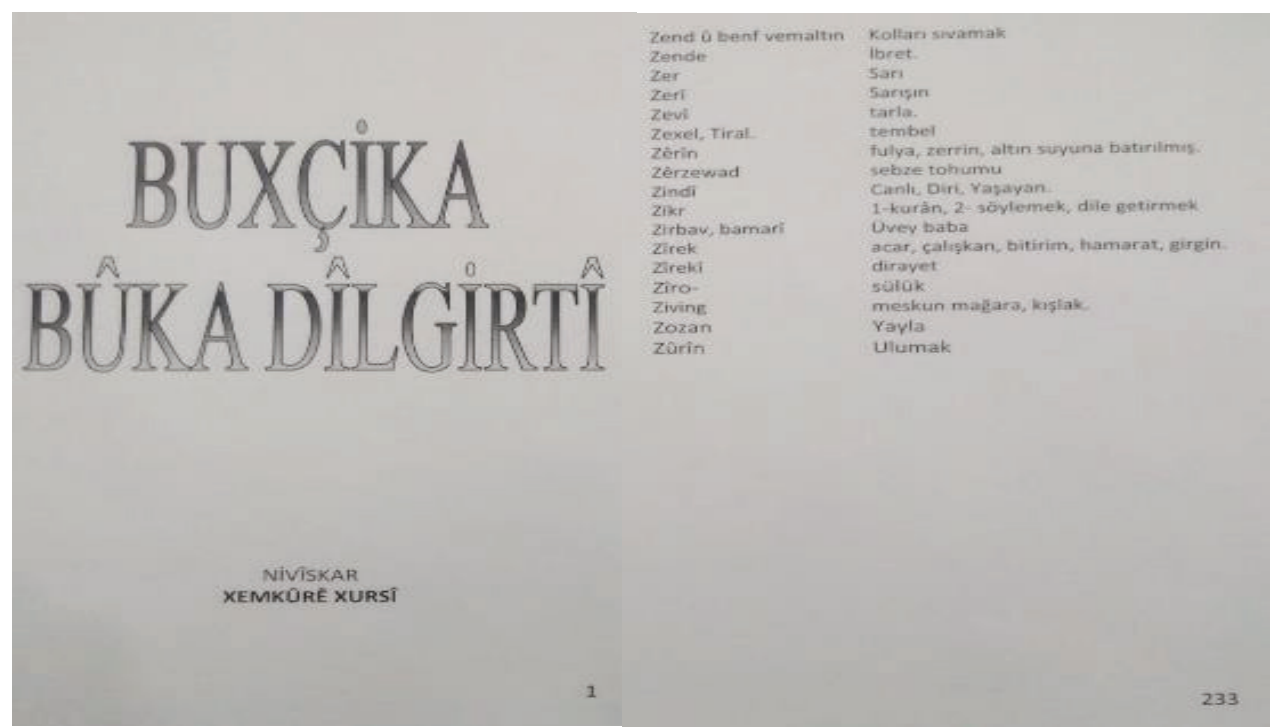




\section{2- Rûpelê pêşî û paşî ji berhema Pirs ĥ Bersivên Ol $\hat{u}$ Dînê Îslamê}

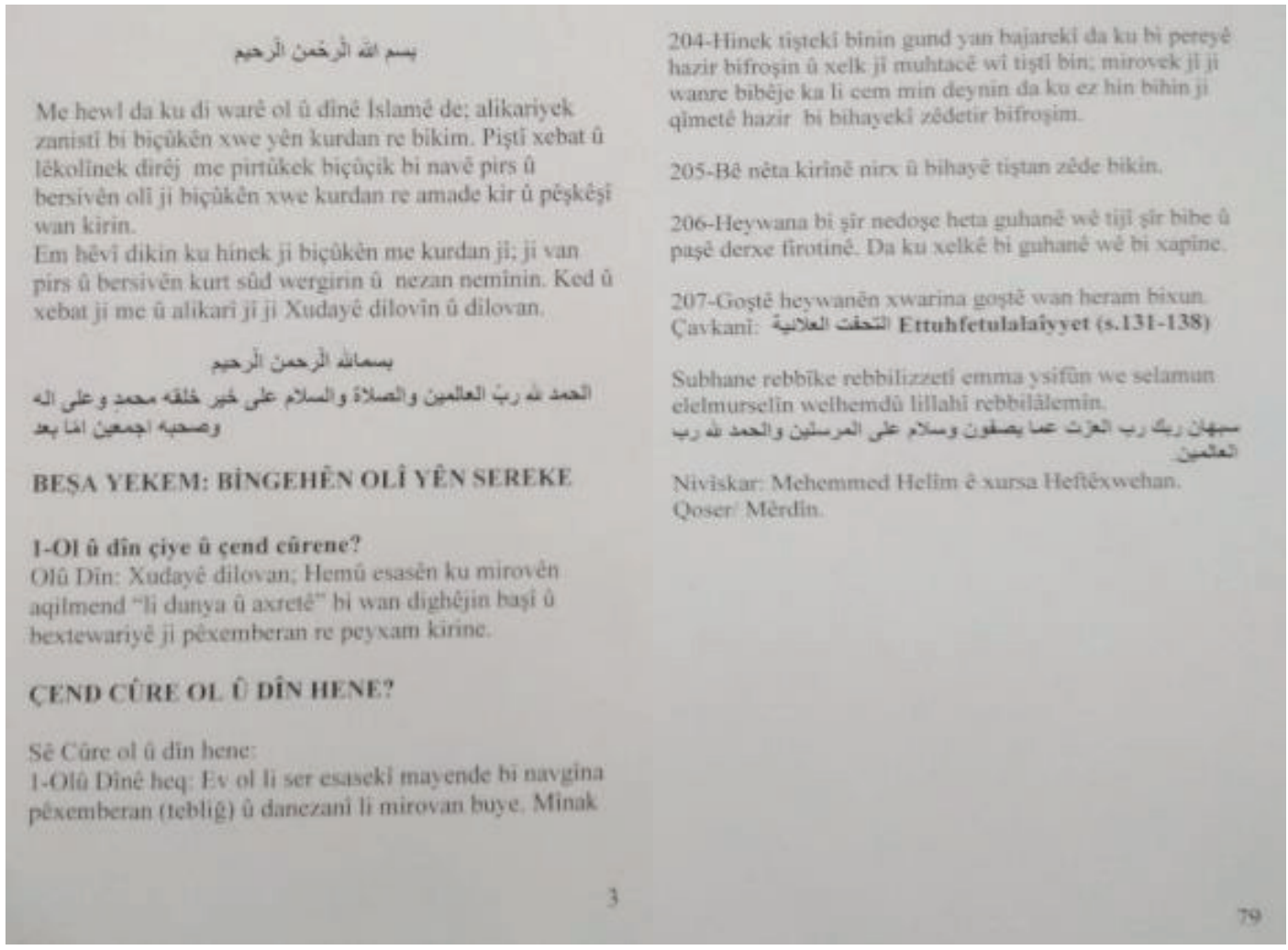

\section{3- Wêneyek Xemkûr}

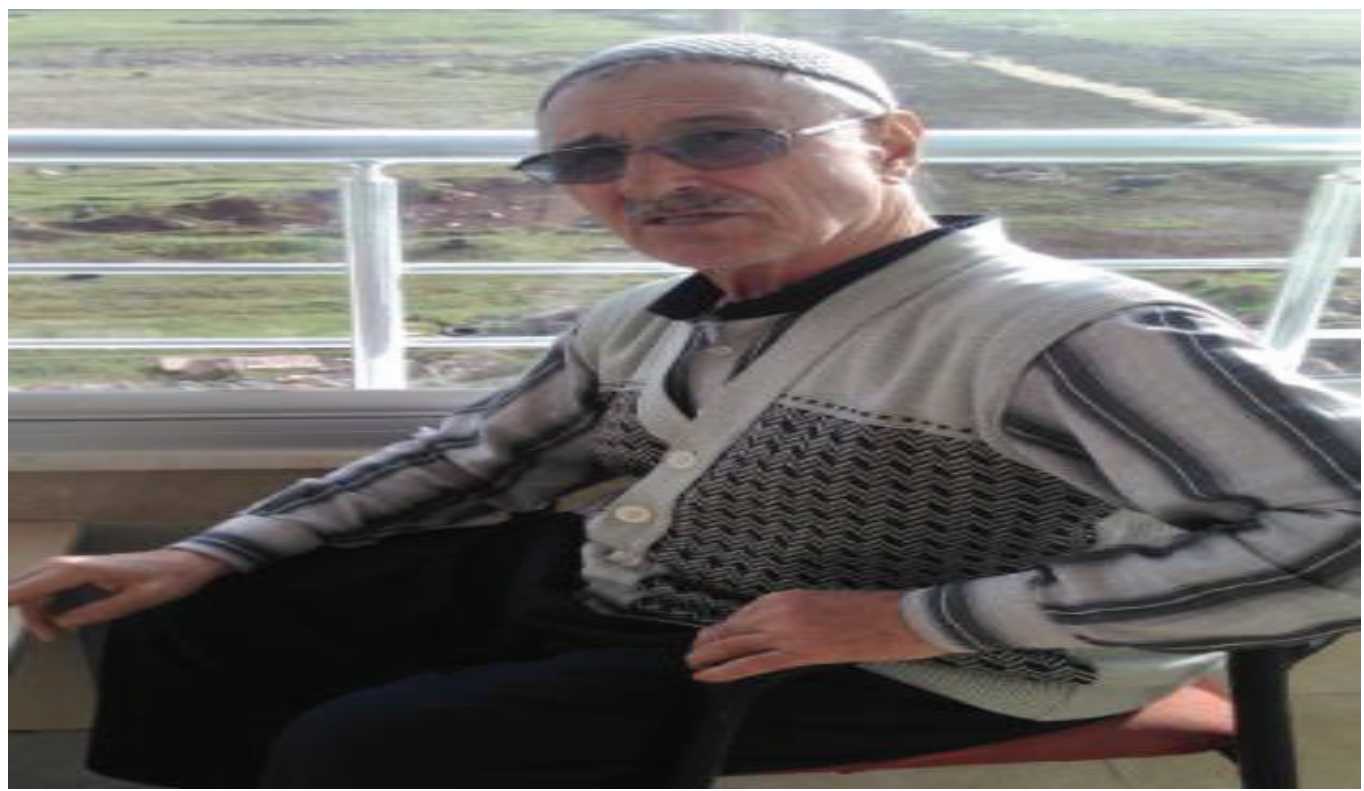




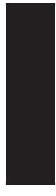

